
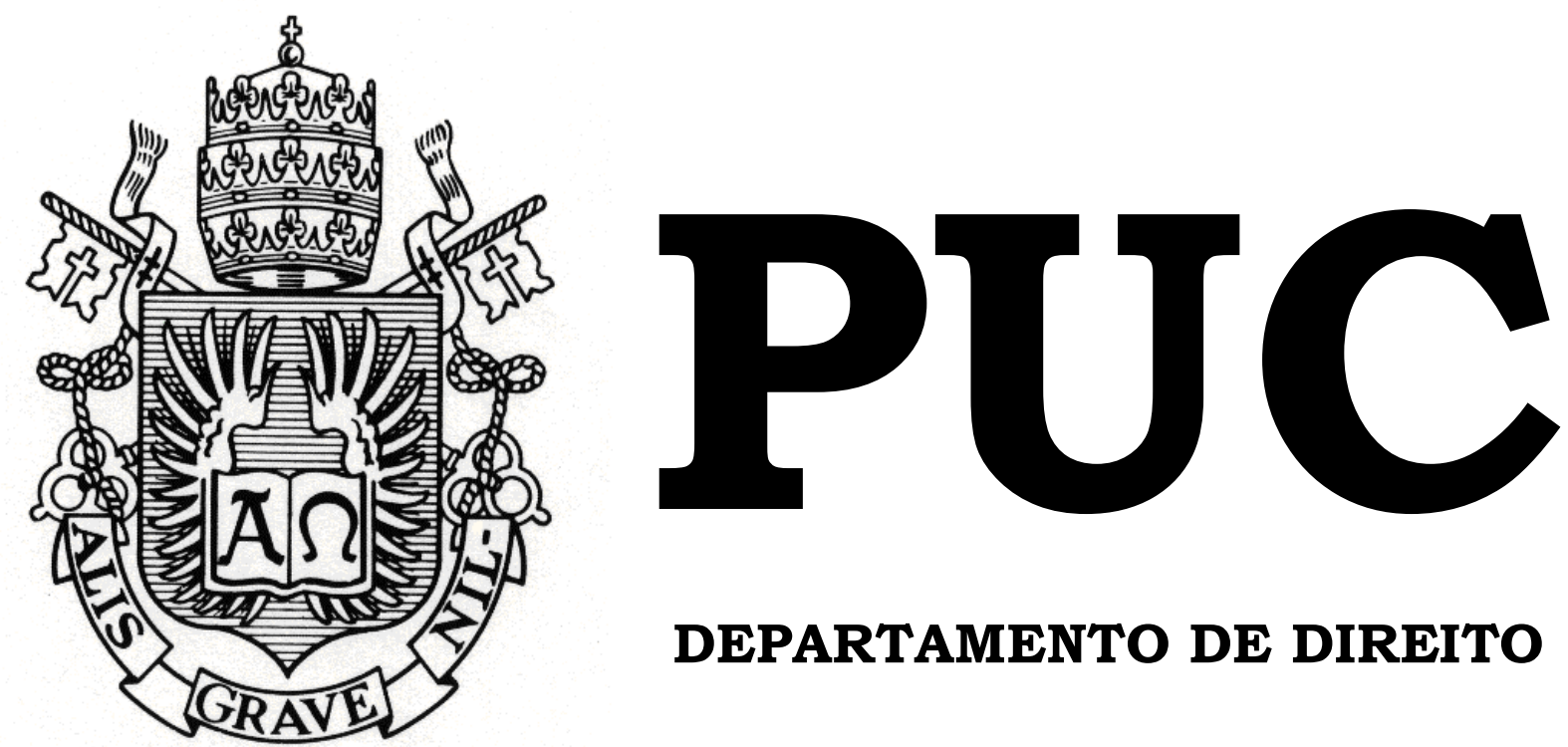

DEPARTAMENTO DE DIREITO

\title{
CIDADE ARMÁRIO: O APAGAMENTO E O NÃO-LUGAR COMO EXPRESSÕES DE UM DIREITO CIS-HETERONORMATIVO
}

Por

GERMANA MARIA GUINLE DE MELLO

ORIENTADORA: THULA RAFAELA DE OLIVEIRA PIRES

2018.2

PONTIFÍCIA UNIVERSIDADE CATÓLICA DO RIO DE JANEIRO RUA MARQUÊS DE SÃO VICENTE, 225 - CEP 22451-900

RIO DE JANEIRO - BRASIL 


\title{
CIDADE ARMÁRIO: O APAGAMENTO E O NÃO-LUGAR COMO EXPRESSÕES DE UM DIREITO CIS-HETERONORMATIVO
}

por

\section{GERMANA MARIA GUINLE DE MELLO}

\author{
Monografia apresentada ao \\ Departamento de Direito da \\ Pontifícia Universidade Católica do \\ Rio de Janeiro (PUC-Rio) para a \\ obtenção do Título de Bacharel em \\ Direito.
}

Orientadora: Thula Rafaela de Oliveira Pires 


\section{AGRADECIMENTOS}

O processo de um primeiro projeto acadêmico com essas proporções com uma temática tão cara a mim, foi um desafio, mas, por sorte, marcado por muitos encontros importantes e rodeado de companhias maravilhosas. Escolher qual mencionar parece impossível, então opto por aquelas mais próximas diretamente desse processo.

Agradeço, em primeiro lugar, à Thula, minha orientadora, que sempre me escutou generosamente e apoiou os riscos acadêmicos para essa pesquisa sair como saiu. Por me acolher mesmo com um tema distante de sua pesquisa, por compreender a relevância dele e permitir que ele tenha esse espaço.

Agradeço a todxs que me guiaram de alguma forma durante esses meses, quando o projeto ainda estava disforme, ajudando a dar corpo ao que era apenas um mar de ideias. Eder, particularmente, que leu tantos préprojetos confusos e noções soltas, com tanto carinho.

Não poderia deixar de agradecer a Aglaia por todas as trocas, apoio em tempos difíceis, pela energia incrível que carrega e a doçura de sempre. Também a minhas irmãs, Ana Júlia, Isadora e Carol, além de amigxs que dão leveza a tudo, com muito amor, risadas e escuta, Ian, Gi, Soph, Ana, Francisco, Mica, Milu, as meninas da defensoria e amigxs da faculdade.

Agradeço muito axs companheirxs de ativismo, que me inspiram todos os dias e me fazem crescer tanto, a galera da TODXS, do TETO, a Luana, Marina, e, particularmente Kellvin e Giovanna do Coletivo Madame Satã, pelos espaços criadxs, discussões imprescindíveis e alegria.

Minha enorme gratidão a Félix por todo brilho que carrega, todas as conversas, choradeiras, consolos, distrações, samba e abraços fortes. Também à Paula, parceira de outras lutas, que sente tudo de forma tão parecida comigo, pela força e alegria que você carrega. Que eu te tenha sempre por perto. 
Por fim, a Larissa, companheira de muitas vidas, que me dá toda a força que preciso, pra escrever sobre esse tema e militar, sempre. Agradeço por toda a escuta, compreensão, carinho e sensibilidade. Ela vibra luta, carregando consigo toda a poesia do mundo. A ela dedico o resultado desse estudo. 


\section{RESUMO}

A cidade reflete relações de poder e valores dominantes de uma sociedade que é cis-heteronormativa, ou seja, assimila como norma social a cisgeneridade e a heterossexualidade, determinando quem serão sujeitos inteligíveis, dignos de direitos; e os abjetos, de quem é retirada a possibilidade de se alcançar direitos sociais que positivam a dignidade da pessoa humana. Cidade-armário é aquela que estende o ambiente de ocultação da identidade de gênero e orientação sexual 'desviante' para ambientes públicos, propiciando o apagamento e o 'não lugar' desses corpos. O direito à cidade é esvaziado pela instauração de um falso consenso, embora se trate de um direito fundamental, produto da soma e inter-relação de diversos direitos sociais, cujo conteúdo pressupõe a gestão democrática da cidade, o conflito, o potencial de politização, a apropriação dela pelos cidadãos e a busca por projetos utópico de cidade. Pessoas LGBTI+ passam a buscar lugares de lazer em espaços específicos e, com a militância, ocupar outras zonas da cidade, já que o lazer social não é realizável na maioria dos locais, pois demanda o conforto em ambientes públicos. O Poder Público permanece criando formas de burlar a concretização de direitos sociais, não formulando políticas de prestações positivas que os garantam. Assim, cumpre-se analisar, nesta pesquisa, através da lente da cis-heteronormatividade, as relações criadas para que o atual contexto social exista e o papel do direito em sua perpetuação.

Palavras-chave: Cis-heteronormatividade; Cidade-armário; Direito à Cidade; LGBTI+; Direitos sociais; Direito ao lazer; lazer social; não-lugar; apagamento; sujeitos inteligíveis e abjetos; gestão democrática da cidade. 
INTRODUÇÃO .6

CAPÍTULO 1 - Cis-heteronormatividade: A neutralidade como padrão excludente 11

$\begin{array}{lllllll}\text { 1.1. } & \text { A } & \text { norma } & \text { jurídica } & \text { e } & \text { o } & \text { sujeito }\end{array}$ LGBTI+ . .11

1.2. Sujeitos inteligíveis e sujeitos abjetos a partir da performatividade.....................................................................................15

1.3. A produção da cis-heteronormatividade e o sentido político da sexualidade...................................................................................22

1.4. Identidade política e sujeitos LGBTI+...................................27

CAPÍTULO 2 - Direito à cidade como Direito Fundamental............... 32

2.1. O conceito de direito à cidade, função social e gestão democrática............................................................................................ 32

2.2. Instrumentos que positivam o direito à

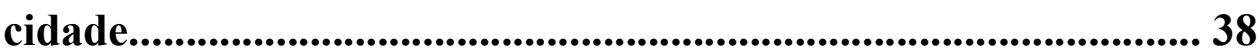

2.3. Espaços públicos $\mathrm{e}$ a produção do nãolugar............................................................................................................. 46

CAPÍTULO 3 - A cidade como espaço de luta e o lazer social, ferramenta de humanização da área

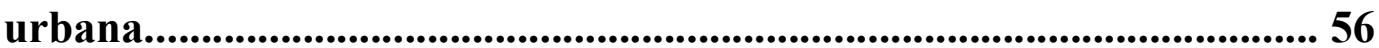

3.1. A acessibilidade a equipamentos de

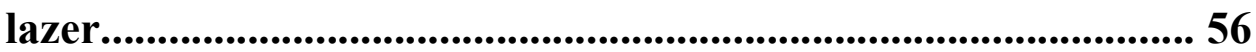

3.2. Subculturas $\quad$ e $\quad$ ocupação

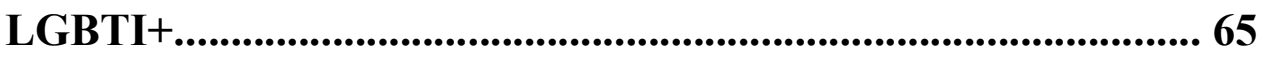

3.3. Direitos sociais $e$ a demanda de atuação

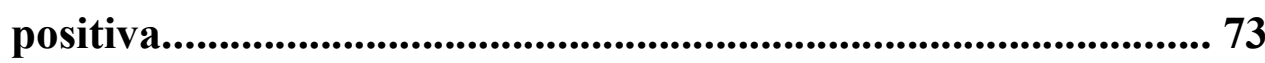

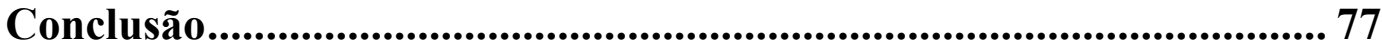

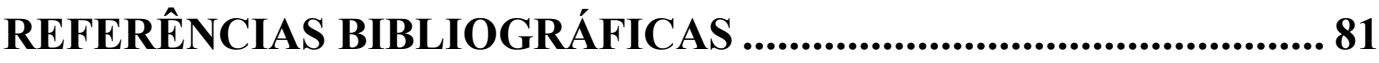




\section{INTRODUÇÃO}

O Brasil, cuja fama é de um local diverso e acolhedor e, portanto, desde 2002 (OLIVA, 2012) já recebeu mais de 250 solicitações de refúgio fundamentados na perseguição por questões relacionadas a sexo, orientação sexual e/ou identidade de gênero (CARVALHO \& FRANÇA, 2017), é o país que mais mata LGBTI+ no mundo, segundo relatório de 2018 do projeto Trans Murder Monitoring (TMM) e dados de 2017 do relatório da Anistia Internacional.

O casamento de pessoas do mesmo gênero foi permitido em 2013 no Brasil, por uma decisão do Conselho Nacional de Justiça, após o julgamento do STF de 2011 que reconheceu a união estável homoafetiva pela primeira vez. A primeira adoção oficial homoparental aconteceu em 2005, em Catanduva, no interior de São Paulo (RIBEIRO, 2017) e, embora não haja regulamentação por lei, a adoção de crianças por casais do mesmo gênero não é proibida, tendo em 2010 o STF se posicionado favoravelmente a essa possibilidade. No final de 2017, o CNJ modificou a certidão de nascimento para constar "filiação", em vez de "pai" e "mãe", mas isso ainda não garante que na prática casais LGBTI+ consigam com a mesma facilidade adotar uma criança. Em 2013, o Conselho Federal de Medicina (CFM) informou que a reprodução assistida será disponível para casais do mesmo gênero.

Diante de portarias $n^{\circ} 457$ e 2.803 do Ministério da Saúde, a cirurgia de redesignação sexual deve ser feita pelo SUS, desde 2008 para mulheres trans $^{1}$, e desde 2013 para homens trans, essa última sendo apenas permitida em hospitais públicos. Ocorre que, poucos Estados têm aparato para realizar a cirurgia e os que o têm ainda contam com outros problemas de infraestrutura. A exemplo, o Rio de Janeiro possui aparato apenas em uma clínica, do mesmo modo que há apenas um médico capacitado para isso,

\footnotetext{
${ }^{1}$ utiliza-se o termo "trans" como termo guarda-chuva que engloba transgênero, transexual e travestis.
} 
que dificilmente consegue realiza-la. Logo, há uma fila quase que estagnada, não garantindo acesso a tal direito (GLOBO, 2018a).

Em março de 2018, o STF determinou que o registro civil de pessoas trans pode ser modificado em cartório, sem a necessidade de comprovação de cirurgia transexualizadora ou autorização judicial. De acordo com a Antra (Associação Nacional de Travestis e Transexuais), ainda há denúncias de pessoas trans que têm esse Direito negado.

De acordo com estatísticas, a cada 19 horas, uma pessoa LGBTI+ é barbaramente assassinada ou comete suicídio no Brasil (Grupo Gay da Bahia, 2017), e por hora, é discriminada (GLOBO, 2018b); a expectativa de vida de pessoas transexuais e travestis no Brasil é de 35 anos (BORTONI, 2017); 82\% das mulheres trans abandonam o ensino médio entre os 14 e 18 anos (GOLDENBERG, 2018); segundo a ANTRA, 90\% das pessoas trans no Brasil acabam recorrendo à prostituição por não terem oportunidade de emprego (KOMETANI, 2017); dxs estudantes LGBTI+ brasileirxs, 73\% foram agredidxs verbalmente e $36 \%$ fisicamente dentro das escolas (CIEGLINSKI, 2016); e do período de 2011 a 2016, 980 pessoas transexuais foram mortas no Brasil (MOREIRA, 2017). Esses dados não são produzidos pelo Brasil, são colhidos por organizações não governamentais, como o Grupo Gay da Bahia ${ }^{2}$, ILGA (International Lesbian, Gay, Bisexual, Trans and Intersex Association) e o ACNUR (Alto Comissariado das Nações Unidas para Refugiados). Além de subnotificado, casos como esses costumam ser apagados, tendo seu fundamento reduzido a outra questão que não a discriminação, o que indica um cenário ainda pior.

A vivência LGBTI+ permanece apagada e sua discriminação também. A falta de políticas públicas específicas para esse grupo torna a cidade um local hostil para que haja o conforto em circular ou de encará-la enquanto um espaço de lazer. O não-lugar muitas vezes faz com que a diversidade de gênero e sexual tenha que ser ocultada e restrita a

2 O Grupo Gay da Bahia é uma das principais referências nacionais em registros de mortes de pessoas LGBTI+, no entanto, seus cálculos são pautados em postagens de redes sociais e notícias de jornal, o que atesta para sua não precisão. 
determinados espaços, que afetam a dignidade da pessoa humana, princípio basilar da Constituição de 1988. Nesta pesquisa busca-se compreender como essa dinâmica se dá na cidade, o que o direito se propõe a fazer e sua efetividade com relação a esses corpos, a partir da análise do lazer social enquanto possibilidade de ocupar espaços com tranquilidade e produzir redes de afeto.

Inicialmente, buscou-se contextualizar os conceitos basilares do estudo de gênero e sexualidade relativos a vivências de pessoas LGBTI+ em relações de poder existentes, a fim de localizar x leitorx nessas questões. Para isso foram lidos autorxs como Judith Butler; Michel Foucault; Yuderkys Espinosa Miñoso; Ochy Curiel; Berenice Bento; Kenji Yoshino e Monique Wittig.

Em seguida, foram analisados os instrumentos normativos que norteiam o tema Direito à cidade, principalmente a Carta Mundial do Direito à Cidade e, simultaneamente, foram lidos autorxs juristas, urbanistas e antropólogxs, como Henri Lefebvre; David Harvey; Virgínia Guimarães; Betânia de Moraes Alfonsin; Edésio Fernandes; Nelson Saule Júnior; Vanessa Oliveira Batista Berner; Heloisa Melino; e Letícia Sabsay, que tratam do assunto, contextualizando esse direito com o atravessamento da demanda deste grupo social.

Por fim, investiga-se a forma que se dá a formação de subculturas, locais de refúgio e de redes de afeto para exercer o direito ao lazer em espaços públicos, diante do apagamento e do "não-lugar" produzido pela cidade, em busca da humanização do urbano. Para isso, utiliza-se, dentre outrxs autorxs, Diane Richardson; Eder Monica Fernandes; Ana Paula Martins; Didier Eribon; Mariana Marcondes; Claudio Oliveira Carvalho; e Gilson Santiago Macedo Júnior; Ana Carolina Mattoso Lopes; Joffre Dumazedier; Raquel Rolnik; e João Luiz Pereira Domingues.

No primeiro capítulo trata-se da cis-heteronormatvidade enquanto um padrão excludente de certos corpos diante das leis brasileiras, como se 
dá a construção de sujeitos inteligíveis e abjetos através da mobilização do conceito de performatividade, o sentido político da sexualidade e a identidade política daquelxs pertencentes ao movimento de militância.

Já na segunda parte da pesquisa, introduz-se o direito à cidade como direito fundamental, os direitos pressupostos na concepção do mesmo, documentos jurídicos internacionais e normas do ordenamento brasileiro. Ademais, contextualiza-se, diante da realidade brasileira e com a lente da normatização da cisgeneridade ${ }^{3}$ e heterossexualidade, ambientes públicos que proporcionam o não-lugar, criando o que Didier Eribon (2008) denomina de cidade armário, ou seja, a ocultação da identidade de gênero e orientação sexual é estendida ao ambiente público.

Finalmente, apresenta-se estudos do lazer, o identificando enquanto humanização da área urbana e direito social que demanda prestação positiva do Estado, constituindo obrigação estatal diante da Constituição de 1988, mas que, no entanto, não é possível de ser acessado por muitxs. Expõe-se formas de militância e resistência de pessoas LGBTI+ dentro das cidades, formas de ocupação de espaços hostis a elas, assim como a formação de subculturas e de redes de afeto em locais específicos.

Faz-se o uso da sigla LGBTI+ com o intuito de representar e incluir outrxs grupos minorizados em relação à orientação sexual e identidade de gênero, além daqueles já representados na sigla LGBT - lésbicas, gays, bissexuais, transgênero, travestis e transexuais, sem que fosse feita uma opção arbitrária de quais outrxs seriam contempladxs. A utilização do "I", que representa intersexuais ${ }^{4}$, se deu pois frequentemente entende-se, dentro do movimento, que não se trataria de diversidade de gênero e sexual, mas

\footnotetext{
3 "cisgênero" é o termo utilizado para definir alguém que se identifica com o gênero o qual foi designado ao nascer.

${ }^{4}$ Intersexualidade é um termo guarda-chuva que inclui aquelxs cujo corpo varia entre os padrões definidos culturalmente para feminino e masculino, com relação à configuração de cromossomos localizados nos órgãos genitais. São pessoas que têm, por exemplo, pênis demasiadamente pequeno, clitórisd muito grande ou formações em que há a coexistência de tecidos testiculares e de ovários. Trata-se de um espectro amplo, muito entendido enquanto patologia que deve ser "reparada" pela mutilação dos órgãos genitais para que se conforme com alguma identidade de gênero, muitas vezes escolhida arbitrariamente, que não necessariamente é a da pessoa.
} 
de questões biológicas, por isso não seriam consideradxs parte da militância. Assim, utiliza-se uma sigla que xs incluam por entender que essa luta deve xs contemplar.

Com relação à linguagem, busca-se englobar todas as identidades de gênero, inclusive as que fogem ao binarismo feminino/masculino, além de entender-se que o plural que coloca o masculino para expressar coletivos que abarque tanto o masculino quanto o feminino seja uma construção gramatical sexista que coloca o homem como neutro, o normatizando. Para isso, utiliza-se 0 "x" nas designações de gênero. 


\section{CAPÍTULO 1. Cis-heteronormatividade: a neutralidade como padrão excludente}

A cis-heteronormatividade é algo intrínseco à nossa sociedade que reflete na cidade, nas estruturas de poder, no direito, na educação, e todos os outros âmbitos, pois permeia a própria forma de ser ver o mundo, de modo quase "natural" para quem é privilegiadx por ela. Aquelxs que mais a percebem são aquelxs que têm seus direitos negados por sua lógica. Ela é responsável por manter um padrão específico no poder e aquelxs supostamente desviantes são excluídxs, por não se enquadrarem em seus requisitos. O "neutro", o "normal”, a "regra" é alcançável para quem se enquadra em padrões específicos, dentre muitos deles, o de ser cis-gênero e heterossexual. Nesse capítulo, pretende-se apresentar conceitos capazes de demonstrar de que maneira opera essa relação.

\subsection{A norma jurídica e o sujeito LGBTI+}

Quase não há legislação específica para pessoas LGBTI+ no Brasil. As conquistas do movimento não alcançaram a legislação, foram apenas possíveis através de interpretações do Judiciário, ou seja, garantias mais frágeis, que ainda mantêm o controle estatal sobre relações afetivas e gênero. A dificuldade encontra-se muito anterior a se pensar como a cisheteronormatividade transpassa todas as esferas. O movimento LGBTI+, diante de muitos retrocessos, luta por estar vivo, segurança pública mínima, por poder se casar ou mudar o nome no registro civil, por exemplo, direitos simples, mas que ainda parecem distantes.

Diante do cenário atual, apresentado anteriormente, Berenice Bento (2017) denomina o que ocorre no Brasil de "LGBTTcídio". Para ela, não se trata "apenas" de LGBTTfobia, uma vez que há ação permanente de assassinatos dessa população sem que haja processos jurídicos instaurados 
ou repercussão internacional suficiente. "O Estado atua como ente que sacrifica legalmente vidas" (BENTO, 2017, p. 55). A cultura nacional é de apagamento das marcas da diferença para ser aceito.

A autora se refere a uma LGBTTfobia cordial, por três motivos. Primeiramente tem-se um aparato legal-jurídico que garante direitos iguais a todxs, dessa forma, o Brasil é visto como um país efetivamente democrático no olhar do estrangeiro, apesar dos dados já apresentados. No âmbito das relações sociais percebe-se que, havendo o pressuposto de igualdade, a responsabilidade pelo fracasso recai exclusivamente sobre o fracassado, isto é, pessoas cisgênero e heterossexuais discursam no sentido de não terem problemas com cis-heterodissidentes ${ }^{5}$, desde que se comportem "devidamente". Efeito disso é o apagamento das condições econômicas, sociais e históricas da realidade de exclusão. Leis somente se tornam realidade se conectadas à consciência coletiva que lhes dê base.

Em segundo lugar, está como se efetivam relações LGBTI+ nas múltiplas esferas sociais. Isto está em debate no Brasil, em que há um crescente de lideranças religiosas LGBTI+fóbicas em instâncias de poder, ao passo em que se tem personagens LGBTI+ em novelas, espaços públicos, na parada do orgulho LBGTI+, expandindo o debate da diversidade de gênero e sexual, embora a visibilidade não seja de forma isonômica dentro do próprio movimento.

Por último, tem-se como elemento a convivência pacífica desde que o outro não cruze determinadas linhas, mantenha-se em determinados espaços, na ilusão da igualdade legal. LGBTI+s "continuarão a ser aceitos, desde que não poluam os espaços públicos com demonstrações de amor e desejo e se mantenham no seu gênero" (BENTO, 2017, p. 59). Isto é particularmente difícil em se tratando de pessoas trans. Esses corpos são a materialidade da impossibilidade de assimilação, apresentam diferenças insuportáveis para a hegemonia dos discursos que definem o sujeito por sua

5 Cis-heterodissidentes são aquelxs que não são cis-gênero ou heterossexuais. 
genitália, assim, é mais difícil de buscar estratégias de aceitação, se quiserem (BENTO, 2017).

Os avanços atingidos no Brasil nunca estão no sentido de garantir uma liberdade irrestrita, mas uma possibilidade a mais, ainda extremamente cis-heterocentrada. Quando possibilitam o casamento de pessoas do mesmo gênero, essa relação ainda está nos padrões de monogamia, por exemplo.

São criadas homonormatividades, ou seja, pessoas LGBTI+ que "se dão respeito", assumem um comportamento discreto, sem levantar bandeiras, e participando de grupos de pessoas cis e hetero ${ }^{6}$. Embora tenha umx parceirx do mesmo gênero, participam de uma cultura e modo de viver cis-heteronormativo, contendo uma postura semelhante, casando-se, relacionando-se de forma monogâmica, muitas vezes mimetizando a "normalidade" cisgênero e heterossexual para ser aceito (SABSAY, 2011). Trata-se de uma aceitação muitas vezes pautada nessas imagens, no entanto ainda distante para muitxs dentro do grupo LGBTI+. Um homem, branco, gay costuma ser muito mais aceito nessas condições do que uma mulher trans negra, por exemplo.

É importante ressaltar que viver um modelo próximo da cisheteronormatividade não é necessariamente uma postura para ser aceito. O casamento LGBTI+ é uma pauta importante dentro do movimento, porque se entende que estamos em uma sociedade na qual essa instituição é muito relevante para todxs e, portanto, pessoas LGBTI+ devem poder ter acesso a esse direito. A cis-heteronormatividade tem também a faceta de tornar mais difícil para pessoas que não se adequam à norma quererem e sentirem que podem viver um modelo de vida semelhante, embora sua orientação sexual ou identidade de gênero seja diversa da hegemônica.

Mantém-se os ideais de organizações de famílias estáveis, mantendo a exclusão invisível, pois em alguns patamares aparenta-se estar mudando o grau aceitação, mesmo que em uma noção reificada e idealizada de

\footnotetext{
${ }^{6}$ Abreviações para cisgênero e heterossexuais.
} 
diversidade, em que os de hierarquia social inferior continuam sendo violentamente excluídos (RUBIN, 1975). O modelo heterocêntrico de família nuclear persiste, como a monogamia, uma figura central que organiza a realidade social, não sendo aceitos modos de subjetivação divergentes (SABSAY, 2011).

Segundo Sabsay (2011), a concepção de diversidade deve ser de uma aceitação acrítica de noções de identidade que não levam em conta normas que implicitamente regulam as formas que as identidades estão obrigadas a assumir para serem reconhecida politicamente. Quando isso não ocorre, geram-se novas formas de exclusão.

Diane Richardson (2000) define os Direitos LGBTI+ em três fundamentos e reivindicações: práticas sexuais, identidade e relacionamento. No contexto da identidade apresenta-se o Direito à autoexpressão, autodefinição e autorrealização. A autoexpressão é o reconhecimento público e social de identidades sexuais, não em um lugar de tolerância ou restrição ao âmbito privado, mas de integração do sujeito através da afirmação de sua identidade na esfera pública.

No Brasil, a iniciativa governamental que se propunha a garantir esse Direito, parte do programa "Brasil sem homofobia", foi revogada após um processo de discussões sobre a proposta de criação de um material educativo que buscava o aprendizado das diversas identidades sexuais no contexto escolar. $\mathrm{O}$ argumento $\mathrm{dxs}$ opositorxs era de que o projeto estimularia a realização de práticas homossexuais (MONICA; MARTINS, 2017).

Já a autorrealização seria a partir da compreensão do exercício da sexualidade como uma cultura sexual, que deve ser exercida sem estigmas ou marginalização. Esta expressão da sexualidade é ligada ao entendimento da heterossexualidade em seu sentido político. "A disputa pelo sentido da sexualidade também é uma disputa pelo poder" (MONICA e MARTINS, 
2017), por isso Richarson (2000) conceitua a autodefinição como um direito inerente ao espectro da identidade.

Há muitas teorias biologizantes da diversidade sexual e de gênero, consequência disto é, por exemplo, a homossexualidade ter sido retirada do rol de patologias pela OMS em 1990 e a transexualidade apenas em 2018. Isto ignora teses como a de Foucault sobre a sexualidade ser uma construção social, uma invenção social e histórica, que será tratada posteriormente. O movimento LGBTI+ costuma utilizar-se de noções essencialistas ou de categorias fixas, mas no sentido de essencialismo estratégico para pleitear Direitos civis e sociais. Para isso, é necessária a garantia do Direito à autodefinição.

Esses elementos são relevantes pois identificam a personalidade enquanto processo de construção através do contato com outrxs, estando em ambientes públicos, relações constituíveis na cidade. Relações de poder a partir de uma norma são concebidas diante da identificação de um sujeito que lhe pertence e um que está a sua margem, logo, é importante compreender como elxs são distinguíveis.

\subsection{Sujeitos inteligíveis e sujeitos abjetos a partir da performatividade}

Performatividade é um conceito mobilizado por Judith Butler, em seu livro "Problemas de gênero" (2017). Essa abordagem é uma forma de se compreender gênero sem a causalidade ahistórica que o determina, ou seja, além da lente em que se centraliza a constituição do gênero como atos, gestos, representações ordinariamente constituídas (BUTLER, 2017), o gênero passa a ser pensado no sentido de fazer-se e construir-se no decorrer do tempo. A Performatividade abarca atos, gestos e desejos que produzem o efeito de um núcleo visível, por meio de ausências e significantes, que 
sugerem, mas não revelam o princípio organizador da identidade (BUTLER, 2017).

A essência ou identidade expressada são tidas enquanto fabricações sustentadas por signos corpóreos e outros meios discursivos. (BUTLER, 2017). Trata-se de uma metalepsis, ou seja, uma antecipação de uma suposta essência de gênero, que produz aquilo que é tido como externo a si, ao mesmo tempo em que esse conceito não vem de um ato singular, mas da repetição e do ritual, concretizados pela sua naturalização no contexto em que o corpo é entendido, culturalmente sustentado na duração temporal (BUTLER, 2017). A antecipação, portanto, deve ser compreendida como parte da temporalidade da repetição:

Como em outros dramas sociais rituais, a ação do gênero requer uma performance repetida. Essa repetição é a um só tempo reencenação e nova experiência de um conjunto de significados já estabelecidos socialmente; e também é a forma mundana e ritualizada de sua legitimação. Embora existam corpos individuais que encenam essas significações estilizando-se em forma do gênero, essa "ação" é uma ação pública. Essas ações têm dimensões temporais e coletivas, e seu caráter público não deixa de ter consequência(...). (BUTLER, 2017, p. 242)

A partir disso se estabelecem as relações de poder, formatando a inteligibilidade dos termos, isto é, o aspecto de coesão, como também sua subversão. Esta seria a torção dos arranjos dispostos, a travessia entre inteligível e x estranhado.

É importante destacar, ademais, que segundo a autora (BUTLER, 1997), que o sujeito não tem controle das ações corporais em sua fala, o discurso acaba trazendo consigo o traço mnêmico do corpo na força que produz. A performance não é um campo ilimitado de auto-enunciação da sexualidade, entretanto, são normas regulatórias de uma sociedade que abrem possibilidades que ele acaba assumindo, apropriando e materializando, não é uma escolha feita pelo sujeito (WEEKS, 2000).

Gêneros inteligíveis são aqueles que, diante do que é considerado correto pela sociedade, mantêm coerência e continuidade entre sexo, 
gênero, prática sexual e desejo. Os incompatíveis com isso são constantemente proibidos, sendo estabelecidas linhas causais de ligação entre sexo biológico e gênero culturalmente construído e sua expressão na manifestação do desejo sexual através da prática sexual (BUTLER, 2017). Essa construção se dá a partir do entendimento de gênero enquanto político e histórico, logo, a "naturalidade" do sexo seria o efeito de sua naturalização discursiva. Explicitar seu caráter performativo, e não expressivo, seria exatamente desestabilizar sua "essencialidade", entendendo que não há identidade pré-existente pela qual um ato possa ser medido, uma identidade de gênero "verdadeira" apenas existe em ficção reguladora (BUTLER, 2017).

De acordo com essa teoria, termos e normas são evocados de forma a exceder e expandir as formas hegemônicas de pensar, ser e fazer. As formas dissidentes podem expandir o pensável. Segundo Zivi, os sujeitos se constrangem pelo que é difícil de imaginar, mas também pelo que as possibilidades permitidas transformam em impensável (ZIVI, 2008).

É possível argumentar que a Performatividade perpassa 3 âmbitos, o corpo, a linguagem e a reivindicação de direitos. Zivi (2008) coloca a subversão política da performatividade pela reiteração que recria constantemente o poder do plano normatizado de inteligibilidade. A isso, Butler (1997) utiliza como exemplo a ressignificação de "falas de ódio" ou a postura de Transformistas, ou drags, que transitam entre a sexualidade binária entre homem e mulher constantemente.

Para que se possa estabelecer uma legitimidade dentro desse padrão existente, oculto nas ontologias humanas liberais (BUTLER, 2011), é necessário representar ou performar outras racionalidades, para que estas se tornem inteligíveis. Performatividade se torna um excesso com a promessa de transformação, não uma mera repetição (ZIVI, 2008). Isto não retira a imanência de seus atos, significa apenas dizer que a circulação desses corpos contém em si uma agência política, de impactar para transformar a realidade. 
Exercer a liberdade e expressar a igualdade precisamente em relação a uma autoridade que impediria ambas é demonstrar que liberdade e igualdade podem e devem se mover para além de sua articulação positiva. A contradição deve ser apoiada, exposta e trabalhada no sentido de algo novo. (BUTLER; SPIVAK, 2011)

A não compreensão de uma existência, que se opõe à norma através de práticas e desejos que não correspondem às expectativas normalizadas, torna essa existência ininteligível. A opção, nesses casos, é a violência da semelhança, reparação ou adequação. Esse corpo se torna um corpo abjeto (MIÑOSO, 2007). Sua mera existência, sua circulação, sua agência é política, pois subverte o padrão e escancara os limites dele. Devemos nos perguntar:

de que maneira o poder atua restringindo mais que a entrada de significação, a saída dela? De que forma a proliferação de novas configurações de gênero e sexo fariam (e estão fazendo) cair por terra os binarismos de gênero, e as redes discursivas de inteligibilidade que permitem o domínio de determinados grupos? De que maneira a forma como operam as redes restritivas de significação e inteligibilidade pode se dar através, não de não se deixar nada fora do seu campo de atuação, mas pela solidificação dos campos de significantes, possibilitando que eles abarquem e acolham em suas variantes, os desvios de todo tipo, sem afetar a forma de interpelação, logo, obrigando-os a entrarem em disputa pelos significantes em si? (MIÑOSO, 2007, p. 95)

O sistema sexo-gênero definiu, dentro da sociedade, a sexualidade biológica diante de produtos da atividade humana (RUBIN, 1975). Ainda que se compreenda que homem e mulher são categorias socialmente construídas, recaímos na ideia de que ambos só podem sentir-se completos se se juntarem.

Mathieu (1971, apud WITTIG, 2006) define a relação de sexo e gênero a partir de 3 configurações: a identidade sexuada, em que o mais importante é o social, diante de uma consciência de gênero coletiva; a identidade sexual, em que prevalece o sexo biológico como natural e determinista; e a identidade de sexo, que se apresenta como classe de sexo, 
de relação social material e histórica entre gênero e sexo, e sua consciência enquanto relação política. Os três âmbitos perpassam pela naturalização da cis-heteronormatividade. Cabe reforçar que sujeitos inteligíveis e sujeitos abjetos são somente assim denominados uma vez que existe uma norma.

Os termos "heterossexual" e "homossexual" derivam de nomeações criadas pelo grupo que está no poder, xs heterossexuais. Já a nomenclatura "cisgênero", em oposição a "trans" (travesti, transexual e transgênero) foi criada pelas pessoas trans (BAGAGLI, 2016). A princípio não seria necessário nomear pessoas enquanto cis, pois seriam a mulher ou homem "normalizados", “de verdade", "biológicxs", "não-trans”, “normais", que têm uma vivência saudável (BAGAGLI, 2016).

A partir dessa nomeação, "corre-se o risco" de passar a legitimar mulheres trans como mulheres e homens trans enquanto homens, de parar de biologizar e genitalizar as identidades trans, de se dar o mesmo tratamento de pessoas cis (SILVA, 2014). Marcar a diferença é uma questão de poder, o que não é nomeado não existe e permanece a norma, portanto, é necessário localizar essas identidades (SILVA, 2014). O fato desse processo ter se dado a partir de uma nomenclatura dada por quem se encontra à margem (ANDRADE, 2014) dá força ao movimento trans, e assusta aqueles que antes não eram nomeadxs. As palavras possuem força, pois fazem nascer conhecimento e percepção.

Dentro de uma sociedade em que sempre o grupo que detém poder se sente no direito irrefutável de ditar as regras e os demais devem acatar, torna-se um incômodo quando isso ocorre perante elxs. Busca-se, então, deslegitimar conceitos como transgeneridade e cisnormatividade (ANDRADE, 2014). Nomear vivências e violências que ocorrem é relevante para a militância e sua visibilidade.

Existem experiências fronteiriças que perturbam esse código binário (cis-trans, homem-mulher, heterossexual-homossexual), desfazendo o ideal de "eu" substanciado e coerente de gênero, demonstrando a importância de 
singularizar as experiências, a limitação dos termos utilizados e a sua força normativa (BUTLER, 2003). Exemplo disto são pessoas não-binárias, que não se sentem confortáveis com a divisão entre gênero feminino e masculino, o que pode ou não significar que se entendem como algo entre os dois gêneros.

O entendimento de que existem "novos sujeitos" é uma noção acadêmica. Na realidade, esses indivíduos já existem há muito tempo, reconstruindo seus corpos e produzindo sentidos originais para relações entre corpo, sexualidade, gênero e subjetividade, embora invisibilizados (BENTO, 2017).

Analisar essas fissuras, diferenças e exclusões sobrepostas é relevante para desconstruir referências binárias e universais que produzem violências epistemológicas aparentemente sutis pela invisibilização (BENTO, 2017). Entende-se como apenas aparentemente sutil, pois é apenas sutil para quem não a vive cotidianamente, quem, por exemplo, não têm, por conta disso, como única opção a prostituição, não é violentado sempre que anda na rua ou tem sua existência questionada e inferiorizada todos os dias. Para pessoas que vivem isso, a violência costuma ser brutal, não sutil, mas alcança até campos em que se torna difícil comprovar, pelo excessivo apagamento.

A disputa dos "novos sujeitos" é a luta para ampliar e tensionar os elementos constitutivos de "humanidade". Abjetos seriam aquelxs que têm negado sua inteligibilidade humana por práticas hegemonicamente legitimadas. Os requisitos para reconhecimento pleno da humanidade não são compatíveis com essas pessoas e até o aparato conceitual de significantes não os alcança. Nessa falha de texto, são instaurados o nojo, a violência e a fobia. Isto deve ser pensado cultural, política e historicamente (BENTO, 2017).

Historiografias oficiais, ao tratarem de narrativas de experiência, buscando legitimar aquelas que por muito tempo foram indignas de 
inclusão, tentam configurá-las enquanto a-históricas. Descarta-se e apaga-se a força constitutiva recíproca que existe pelo inter-relacionamento de ambas durante a história, que as colocou como opostas (SCOTT, 2012). Scott, Foucault, Weeks e Butler, assim como outrxs pensadores, já compreendem tais identidades como socialmente construídas, performadas e atualizadas, constituindo dispositivos de poder, políticos e politizáveis (CURIEL, 2013).

Em sua maioria, embora de forma estratégica, movimentos sociais acabam legitimando a máquina do biopoder do Estado, uma vez que demandam políticas específicas para corpos específicos, o que essencializa a noção de "identidades" (SCHETTINI, 2013). Em muitos casos, essa demanda somente será considerada legítima quando proferida por quem está contido nessa identidade essencializada. Os estudos transviados, ou queer, buscam desnaturalizar identidades sexuais e de gênero, entendendo a noção de diferença como constitutiva dos arranjos identitários (BENTO, 2017). Deve-se atentar, no entanto, para não recair em autonegação, que seria apenas a internalização da inferioridade (FANON, 2008).

Judith Butler aborda a emergência da subjetividade diante do reconhecimento e endereçamento:

Alguém vem a existir pela dependência fundamental do endereçamento do Outro. Alguém existe não apenas pelo fato de ser reconhecido, mas em sentido anterior, em ser reconhecível. Os termos que promovem o reconhecimento são estes mesmos convencionais, os efeitos e instrumentos de um ritual social que determina, frequentemente através da exclusão e da violência, as condições linguísticas da possibilidade de sobrevivência dos sujeitos. (BUTLER, 1997, p. 05)

Assim, a formação social da subjetividade estaria implicada no endereçamento da fala do outro, que pode ser questionada, mas demandam um grau de repetição (BUTLER 1997). É necessária a criação de um enquadramento para que identidades possam "emergir", portanto, elas se dão a partir de uma ficção de sujeito inteligível (BUTLER, 2015). 
Para a legislação reconhecer sujeitos, elxs precisam ingressar no reino da aparência ou serem posicionados nele. Em muitas situações elxs são moldados para aparecer perante a lei, não sendo plenamente determinados por ela, por estarem somente implicados em alguma situação (BUTLER, 2015). Isto será tratado adiante.

\subsection{A produção da cis-heteronormatividade e o sentido político da sexualidade}

Para compreender a heterossexualidade, é necessário não se ater ao erotismo, à identidade sexual, opção sexual e comportamento e práticas sociais. Dificilmente ela é abordada enquanto instituição ou regime político, no entanto, analisar a construção da sexualidade e o significado de suas práticas, domínios comportamentais, do corpo, pulsões, mediatizações culturais do que lhe é anterior, como produtos e produtores de reprodução social, é de extrema relevância (CURIEL, 2013). "Devemos entender que a produção da heterossexualidade é um projeto diário e violento" (BENTO, 2017, p. 198)

Sujeitos cis-heteronormativos são aqueles que enxergam a heterossexualidade como única forma legítima de viver a sexualidade, também ignorando sua pluralidade intrínseca. Relações LGBTI+ tornam-se desvios, crimes, aberrações, doenças, pecado e perversões. Reduz-se a sexualidade ao fator reprodutivo e codifica como correta uma forma específica dela ser realizada (JUNQUEIRA, 2003).

Para Viviane Vergueiro (2015), a cisnormatividade enquanto categoria analítica pode ser descrita em três aspectos: a pré-discursividade; a binariedade; e a permanência dos gêneros. O primeiro diz respeito à inscrição no discurso das marcas corporais relacionadas a um suposto sexo biológico que são entendidos como critérios naturais e objetivos para que se defina o sexo-gênero. A binariedade constitui a dualidade limitadora de 
alternativas para definir-se, ou seja, "corpos normais" serão macho ou fêmea; e a permanência seria a consagração de uma constância necessária da identificação do gênero designado com base no sexo, materializada nas expectativas de gênero associadas a homem e mulher.

De acordo com Monique Wittig (2006), a categoria sexo é produto da sociedade heterossexual, uma vez que não é uma questão de ser, mas de relações. Ao constituir uma diferença é possível controlá-la, como ato de poder, como ato normativo. É com bases nessa diferença que os sujeitos passam a definir seu lugar no mundo.

Os discursos de opressão de pessoas LGBTI+ se pretendem verdadeiros, não como uma mera opinião, sendo justificados cientificamente e enunciados enquanto algo apolítico, embora espaços apolíticos sequer existam. Não seria discutível, nessa lógica, que o gênero que você é designado ao nascer é o "real", que se identificar conforme ele seria o "natural". Eles oprimem na medida em que negam toda a possibilidade de se falar em termos que não sejam compartilhados, assim como quando relações pautadas pela heterossexualidade são colocadas enquanto primárias, normais, neutras. Nega-se a esses sujeitos a possibilidade de criar suas próprias categorias (WITTIG, 2006).

A linguagem se desloca para um lugar central, pois dela emana a nomeação dos corpos e sexos, produz sujeitos, identidade e suas práticas. Como dito anteriormente, esse discurso não é somente constituído de heteronomias, abre também espaço para abjetos, aqueles dissonantes, que excedem esse conceito. (MONICA \& MARTINS, 2017).

O sentido convencional para expressar normas com caráter universal torna-se impróprio na medida em que movimentos vão conseguindo espaço. Não significa, entretanto, que essas minorias têm um critério mais verdadeiro de universalidade, mas que, através delas, é exposta a característica limitadora e exclusiva daquele conceito, e mobiliza-se isto para pleitear demandas do movimento (BUTLER, 2000). 
A partir do uso estratégico desses termos "inteligíveis", é possível realizar uma transformação política (WITTIG, 2006), o que, posteriormente, pode ocorrer com aquilo que foi utilizado como a substituição do modelo hegemônico anterior (BUTLER, 2000).

Normas criam conceitos implícitos, de homem, mulher e sexo, por exemplo, que são pautados na diferença dos sexos, criada por uma opressão (WITTIG, 2006). Uma das definições implícitas da cisgeneridade e heterossexualidade enquanto norma de modelo hegemônico é o significado de feminino, que faz com que mulheres se vejam a partir dos olhos masculinos (MIÑOSO, 2007), xs indicando enquanto complementares.

Para além disto, a heterossexualidade obrigatória trouxe a ideologia do romance heterossexual, em que se naturaliza o desejo de mulheres por homens, as assegura em posições menos valorizadas na divisão do trabalho, como domésticas, empregadas ou educadoras, e sexualiza o trabalho em si, que passam a ocupar a partir de sua sexualidade. Assim, mulheres lésbicas devem negar-se, tanto com relação a sua aparência física quanto seus comportamentos, para permitir que homens acreditem ter acesso físico, econômico e emocional a elas (RICH, 2003). Para Adrienne Rich (2003), Lésbicas seriam uma ruptura de tabu, o desprezo de um modo de vida obrigatório, como também o ataque ao direito masculino de acesso às mulheres.

Segundo Wittig, a apropriação se dá no âmbito privado, ou seja, direto, por pais, maridos e noivos, mas também no coletivo, da classe de homens, da relação entre público, trabalho, racionalidade, destinado ao masculino, e privado, casa, emoção destinado ao feminino. Isto deve ser combatido no plano material, e também no conceitual, abolindo categorias que criem um abismo entre si (WITTIG, 2006).

É de extrema relevância esse apontamento para compreender a conexão da cis-heteronormatividade com o campo político. A constante perpetuação de tais premissas se dá pela desigualdade social e política, que 
mantém o poder decisório nas mãos de poucxs, privilegiadxs, que evidencia o entendimento restrito e unitário de "progresso". Conceitos como esse, selecionados por um grupo, que invisibiliza a desigualdade (CURIEL, 2013). Nesse raciocínio, o pacto social foi criado por um homem, que é racional, neutro e imparcial, características supostamente impossíveis de se encontrar em mulheres, o que os dariam aptidão para tal (CURIEL, 2013).

A lógica trazida na Constituição, de que todxs xs cidadãxs nascem livres e iguais e têm os mesmos direitos, é em si falha, pois não considera quem não se enquadrará efetivamente nas categorias da legislação, uma vez trazidas para a realidade (CURIEL, 2013). Na prática, é aquele mesmo homem "racional" e "autônomo" que se encaixa também nas normatividades hegemônicas, de que dependem os direitos.

Essa definição traz consigo o ideal de cidadania moderna e universalista, ao mesmo tempo em que se tratando de fatos, esta é prémoderna e particularista (CURIEL, 2013). O contrato social, para que funcione, necessita de um contrato sexual implícito, embora nunca tenha sido firmado ou não alguns grupos estivessem em condições de igualdade para firmá-lo, o que leva à exclusão de determinadas pessoas dele enquanto sujeitos (CURIEL, 2013).

Quando a Constituição utiliza o conceito de homem e mulher, os coloca enquanto categorias homogêneas, ahistóricas e antagônicas, além de apresentadas no singular, como se só houvesse uma forma de ser homem ou mulher (CURIEL, 2013). Ademais, não são escritas palavras como "cisgênero", "heterossexual", brancx, dentre outros. Elas não têm existência jurídica, mas têm efeitos, pois sua omissão advém da pressuposição de sua existência (CURIEL, 2013).

Foucault (1988) explica que o próprio mutismo, o que não é dito ou se proíbe de dizer, a discrição, seria também elementos manipulados assim como coisas ditas. As maneiras como um discurso é encarado como um todo deve levar em conta o silêncio que o atravessa e o que é autorizado. O 
"armário", a ocultação de pessoas LGBTI+ é ao mesmo tempo fala e silêncio.

Para que haja uma isonomia, são necessários o reconhecimento da discriminação de certos grupos e a politização do que historicamente esteve restrito ao âmbito doméstico, como o controle do corpo, da sexualidade e da reprodução, buscando romper com a definição de lugares "naturais" e certos discursos políticos (CURIEL, 2013). A reivindicação por grupos excluídos de Direitos ditos universais, deve se dar, primeiramente, pela contestação da noção de humanidade, que não os abarca e não garante a eles os efeitos dessa tutela (BUTLER; SPIVAK, 2007)

Reconhecer esse discurso que permeia o âmbito biológico, moral, espiritual, econômico, social, cultural e político (CURIEL, 2013), é compreender que a ideia de nação e progresso, se dá a partir do sistema de relações sociais cis-heteronormativas que, por sua vez está intrínseca à organização da sociedade, aos domínios comportamentais, assim como redes de casamento, parentesco, a família, vida doméstica, escola, medicina, alianças políticas, vestimenta, divisão sexual do trabalho e moradia, não se restringindo ao sexo estrito senso (CURIEL, 2013).

Biopolítica é um termo utilizado por Foucault (2004), significando a prática de biopoderes locais. O biopoder teria como alvo e instrumento a população, colocada em uma relação de poder para a controlar. Segundo ele, os problemas da prática governamental são racionalizados, através de atributos próprios da população, como saúde, higiene, natalidade, costumes, longevidade, raças, etc. Explica-se, por esse conceito, como discursos levam hábitos sociais a serem aceitos ou repudiados. Isso ocorre com a diversidade de gênero e sexual, que é controlada na suposta busca de manter a saúde, higiene e reprodução, por exemplo, legitimando a cisgeneridade e heterossexualidade.

A sexualidade vai sendo controlada e restringida através de discursos úteis e públicos, desqualificando suas variações, o que Foucault chama de 
Polícia do sexo (1988). Trata-se de regimes veridicionais, em que se diz o que é ou não verdade, mediante um discurso hierarquizado, facilitado pela censura do vocabulário (FOUCAULT, 2004). O homem e a mulher são colocadxs em pólos opostos, limitando a identidade de cada um a padrões consagrados, sendo o masculino forte, público, e mulheres frágeis e privadas. Aquele que foge desse parâmetro terá seu gênero e sexualidade questionados, como o homem que perdeu a virilidade por não gostar de esportes violentos (FOUCAULT, 1984).

Goffman (1968) distingue a Identidade Social Virtual da Identidade Social Real: a virtual seria aquela de acordo com estereótipos de uma identidade estigmatizada, já a real aquela como o indivíduo de fato se apresenta. Devemos perceber as imagens fixas que constroem essa Identidade Social Virtual para analisar a relação delas com os discursos sobre a produção e significação de diferenças culturais articuladas. Isso pode ser observado a partir da análise de discursos, mas também compreendendo a Performatividade.

Exemplo de elementos sociais produzidos pela racionalidade da prática governamental é a naturalidade do casamento entre homem e mulher enquanto fundamental para a vida em sociedade. Isso se dá através de discursos iniciais como a procriação, necessidade de prolongar uma ligação estável para assegurar a educação dos filhos, conjunto de recursos, a comodidade, segurança, que criam essa aliança "legítima" e supostamente única e verdadeira, para que haja a formação da família por um casal de homem e mulher cis, monogâmico, heterossexual, que constituiria elemento básico para a cidade, mas incapaz de abarcar todos os múltiplos desejos existentes (FOUCAULT, 1984).

\subsection{Identidade política de sujeitos LGBTI+}


Preliminarmente, é necessário constatar que um sujeito somente se torna distinto pela exclusão de outras possíveis formações de sujeitos, "nãoeus". Assim como, para sua formação, é necessário abandonar dimensões de si que não se conformem às figuras distintas produzidas pela norma do sujeito humano (BUTLER, 2015).

(...) constituir meu caráter distinto e específico permanece em mim como a perspectiva de minha própria dissolução. Qualquer diferenciação interna que eu possa fazer entre minhas partes ou minhas "identidades" depende de algum modo de unificar essas diferenças, e, assim, reinstala o sujeito como fundamento da própria diferença. Por sua vez, esse sujeito adquire sua especificidade definindose em oposição àquilo que está fora dele, de forma que a diferenciação externa se mostra fundamental para explicar a diferenciação interna também (BUTLER , 2015, p. 203).

Duas categorias identitárias se colocam enquanto uma relação conflitiva, sendo difícil limitar perfeitamente uma ou compreender o local de convergência sociológica entre elas, o que leva ao apagamento de complexas realidades, pois ordenar identidade reais de acordo com exigências de um conceito. São enquadramentos normativos que determinam certa "ignorância" sobre os sujeitos em questão, inclusive racionalizando-os à medida em que é necessária para a incidência política (BUTLER, 2015). Um enquadramento binário pressupõe o entendimento completo de uma realidade complexa, sem que seja feita qualquer investigação. Isto mantém um modelo normativo, que necessita de um mapa da realidade para assegurar certos comportamentos e privilégios (BUTLER, 2015).

De acordo com Butler (2015), a vantagem de enquadrar-se dentro de uma categoria é a força estratégica que se tem diante de direitos de grupo, todavia, é necessário que pensemos em outras propostas de unidades. Isto porque o reconhecimento enquanto grupo pode acabar por regular os sujeitos de acordo com normas já pré-estabelecidas, que muitas vezes se provam estar pautados em um reconhecimento falho. Exemplo disto é quando Monique Wittig anuncia que “a lésbica não é mulher” (2006), 
demonstrando que o conceito de mulher do feminismo e do machismo enquanto regulação binária, não a abarcava enquanto mulher lésbica. Muitas vezes, opressões se interseccionam, e o movimento de militância não consegue abarcar todos aqueles sujeitos implicados em uma categoria analítica.

É de extrema relevância observar isso no caso de pessoas LGBTI+ e o avanço das siglas para designá-las. Inicialmente abarcando apenas homossexuais, passa-se a compreender uma grande diversidade de pessoas através de apenas um grupamento, abrangendo inclusive a identidade de gênero.

As categorias de diversidade de gênero e sexuais são construções forjadas instrumentalmente para a luta política de reivindicação de direitos, sendo parte delas criadas no intuito de criminalizar condutas, mas nenhuma é atemporal. Assim, é importante analisar os impactos dessas disputas a partir das identidades, mesmo compreendendo que elas se reinventam constantemente.

Tem-se uma ontologia que legitima a cis-heteronormatividade, e que se tem como contraposição pessoas transexuais, transgênero, travestis, lésbicas e gays que, mesmo que discriminados e colocados enquanto identidades degradantes e estigmatizadas, são "entendidas" pelo fato de se contraporem ao modelo hegemônico, permeando, de forma lógica, ontologias definidas enquanto eternas, impermeáveis, integralmente separadas e simétricas, embora nem sempre sejam. Nesse momento, buscase compreender o lugar das identidades que transitam entre esses dois patamares opostos e que desestabilizam a divisão social da sexualidade.

Com relação à sexualidade, a imposição colocada, ao se pensar de modo binário ${ }^{7}$, é a monossexualidade. Essa categoria analítica engloba pessoas que se atraem por apenas um gênero, como heterossexuais, gays e lésbicas (YOSHINO, 2000), que se contrapõem a "não-monossexual" ou

${ }^{7} \mathrm{O}$ binarismo está em se compreender o mundo pautando a humanidade a partir de duas categorias de forma totalizantes, em detrimento de reconhecer sua pluralidade interpretativa. 
"monodissidentes", conceito utilizado para se entender esse movimento como resistência politizada às estruturas vigentes da sexualidade, tal como bissexuais, pansexuais, polissexuais ou plurissexuais ${ }^{8}$ (LEÃO, 2018). Essa resistência seria no sentido de não aceitar o desejo homoerótico e heteroerótico como pertencentes a territórios separados (YOSHINO, 2000).

Por transitar entre ambos os grupos sociais, bissexuais muitas vezes são caracterizados enquanto uma identidade transitória, de pessoas indecisas, não-monogâmicas, promíscuas e vetores de doenças sexualmente transmissíveis, tendo a constante necessidade de comprovação de sua sexualidade sempre questionada (LEÃO, 2018). Muitas vezes são descritas por terem falta de limites morais e sexuais, além do estereótipo de serem algo perigoso. Assim, pessoas mais jovens costumam ter mais facilidade em se designar bissexuais e, em faixas etárias maiores, não se observa a mesma proporção (LEÃO, 2018).

Trata-se de um desejo inconcebível à compreensão da humanidade estática. A representação de heterossexualidade e homossexualidade enquanto polaridades opostas, torna vivências que navegam entre eles sem se fixar, contaminadoras. Para mulheres, pode significar habitar o espaço do Outro em duas esferas: diante da moral da família, lidando com desejos e vivências que não estão relacionadas ao fetiche masculino, ao passo em que, dentro de "espaços sapatão", ou seja, de acolhimento de mulheres lésbicas, há muitas vezes a construção romântica de que lésbicas estariam puras e livres da força opressora dos homens, não cabendo o acolhimento de pessoas monodissidentes (LEÃO, 2018).

A cis-heteronormatividade atinge esses grupos, não mais do que pessoas que se adequam à binariedade de gênero ou monossexuais, mas de uma forma diversa. Utilizou-se o exemplo da bissexualidade, mais especificamente de mulheres cis bissexuais, a título ilustrativo apenas para

\footnotetext{
8 Embora não sejam monodissidentes, cabe ressaltar ainda quem se identifica como parte do espectro assexual. É impossível mencionar e explicar todas as identidades de gênero e orientações sexuais, uso aqui exemplos para demonstrar questões específicas da cis-heteronormatividade.
} 
se demonstrar outros efeitos da normatização da identidade de gênero e sexual, sua extensão de proporcionar o não-lugar de muitos corpos.

É relevante a utilização desses enquadramentos normativos a título de militância, busca de identificação para além do normativo e reivindicação de Direitos, no entanto, mantendo uma visão crítica, sem que essas categorias permaneçam incontestadas e incontestáveis, causando novas relações de poder e discriminação:

Quando constituem a base de coligações políticas, essas comunidades estão unidas menos por questões de "identidade" ou termos de reconhecimento comumente aceitos, do que por formas de oposição política a certas políticas estatais e outras políticas regulatórias que efetuem exclusões, rejeições, suspensão parcial ou plena da cidadania, subordinação, degradação ou coisas assim. Nesse sentido, as "coligações" não estão necessariamente baseadas em posições do sujeito ou na reconciliação de diferenças entre posições do sujeito; na realidade, podem estar fundamentadas em objetivos provisoriamente sobrepostos e pode haver - talvez deva haver - antagonismos ativos a respeito do que esses objetivos deveriam ser e da melhor maneira de alcançá-los. Elas são campos animados de diferenças no sentido de que "ser produzido por outro" e "produzir outro" são parte da própria ontologia social do sujeito, situação em que "o sujeito" é menos uma substância distinta do que um conjunto ativo e transitivo de inter-relações. (BUTLER, 2015, p. 210)

A sigla LGBTI+ tem crescido cada vez mais no sentido de abarcar diferentes movimentos e identidades distintas que não se sentiam representadas pelo movimento. É relevante que essa visibilidade ocorra, uma vez que o sentido da cisgeneridade e da sexualidade é também uma disputa pelo poder, e identidades abrangentes se distanciam de especificidades importantes.

Diante das dificuldades abordadas sobre a formação da identidade, o contato com x outrx e os processos diante da cis-heteronormatividade, deve-se compreender qual papel o Direito buscou ter na concretização do espaço e das relações da cidade, ao instituir diversos direitos fundamentais. 


\section{CAPÍTULO 2. Direito à cidade como Direito Fundamental}

O Direito à cidade pressupõe um ambiente urbano em que haja conflitos, xs cidadãxs possam se apropriar dele para garantir que sua própria noção de cidade seja concretizada, diante de projetos utópicos, e a partir da gestão democrática, assegurando sua função social. Para isso, não se pode manter um consenso aparente, pela opressão dos projetos de cidade visados pela minoria. A construção desse direito no âmbito internacional e no ordenamento brasileiro ainda tem um longo caminho para que ele seja efetivado, ainda mais perante a cis-heteronormatividade, pouco referida quando questionadas as relações de poder da cidade. Neste capítulo, buscase conceituar esse direito, com base em seus elementos e nas normas que visam o positivar.

\subsection{O conceito de direito à cidade, função social e gestão democrática}

Embora ocupe um espaço central em movimentos sociais hoje em dia, o Direito à cidade, por ter uma dimensão multifacetada e abarcar diversos direitos fundamentais, muitas vezes tem seu significado esvaziado, se tornando mera abstração, cuja materialização é um desafio. Seu amplo potencial de politização é prejudicado por sua utilização enquanto um conceito vago que apenas legitima uma cidade excludente. Assim, neste capítulo, busca-se delimitar essa definição, a partir de seus princípios, elementos fundantes e formalizações legais no âmbito internacional e no ordenamento jurídico brasileiro, além de compreender as formas como são concretizados esses preceitos.

Com esse objetivo, é relevante compreender o sentido de cidade. Para Lefebvre (2001), ela constitui a práxis da sociedade urbana, sendo um objeto virtual, de impossível determinação genérica e ampla. Sua análise, 
para compreender o Direito à cidade, nunca será definitiva ou exaustiva, mas demandará a delimitação de um período histórico para se construir e orientar a prática social. Segundo o autor, não se trata de algo de simples caracterização, deve-se analisar o conjunto de práticas e relações sociais que se constituem no ambiente das cidades:

\begin{abstract}
Através dessas necessidades específicas vive e sobrevive um desejo fundamental, do qual o jogo, a sexualdiade, os atos corporais tais como o esporte, a atividade criadora, a arte e o conhecimento são manifestações particulares e momentos, que superam mais ou menos a divisão parcelar dos trabalhos. Enfim, a necessidade da cidade e da vida urbana só se exprime livremente nas perspectivas que tenham aqui se isolar e abrir os horizontes. As necessidades urbanas específicas não seriam necessidades de lugares qualificados, lugares de simultaneidade e de encontros, lugares onde a troca não seria tomada pelo valor de troca, pelo comércio e pelo lucro? Não seria também a necessidade de um tempo desses encontros, dessas trocas? (LEFEBVRE, 2001, p. 105-106)
\end{abstract}

Deve-se considerar, portanto, para quem se irá construir a cidade e como construí-la, objeto esse que está em constante transformação. A criação de instrumentos para tal é impossível para arquitetos, sociólogos ou políticos apenas, pois trata-se de um local de contradição, dissenso e encontros, isto é, não comporta projetos uniformizadores, que promovam a despolitização de conflitos urbanos e que desvaneça a capacidade criadora da cidade, que lhe é intrínseca (LEFEBVRE, 2001).

O Direito à cidade, segundo Harvey (2014), não envolve apenas acesso ao que existe ou sua relação com os recursos incorporados nela, mas o direito de reconstruir e recriar a cidade, de transformá-la. Refere-se a um direito que envolve necessariamente o exercício de um poder coletivo sobre o processo de urbanização de acordo com os desejos dxs cidadãxs (HARVEY, 2014).

De acordo com Lefebvre (2001, a função social da cidade somente pode ser realizada através de estruturas diferentes, não sendo possível uma ligação unívoca entre os termos. A estrutura, função e forma constituem um todo que é mais do que esses aspectos tidos separadamente, quando 
integrados na prática social (LEFEBVRE, 2001). Seu pressuposto é a existência de um espaço para o desenvolvimento da vida política, dando origem a projetos utópicos de cidade. $\mathrm{O}$ direito à cidade não é o de viver em cidade, como o conceito tradicional, mas o "Direito à vida urbana, transformada e renovada" (LEFEBVRE, 2001, p. 117-118), locais de encontro e de troca, ritmos de vida e "empregos do tempo que permitem o uso pleno e inteiro desses momentos e locais" (LEFEBVRE, 2001, 138139), diante dos apelos e exigências de seus habitantes.

Para Nelson Saule Júnior (2005), função social da cidade, que passou a ser no Brasil princípio constitucional de política urbana, é:

o uso socialmente justo do espaço urbano para que os cidadãos apropriem-se do território, democratizando seus espaços de poder, de produção e de cultura, dentro de parâmetros de justiça social e da criação de condições ambientalmente sustentáveis (SAULE JÚNIOR, 2005, p. 4)

Assim, a ideologia que pretende dar caráter absoluto de "cientificidade" a um projeto de reforma urbana, está tratando um objeto virtual como objeto técnico, como se elementos dele constituíssem uma totalidade (LEFEBVRE, 2001). A omissão estatal ou ação estatal tecnocrática tem como consequência a perpetuação do padrão excludente da urbanização no Brasil (FERNANDES, 2007).

Nesse sentido, o Direito não pode ser entendido enquanto um sistema objetivo, fechado em si próprio ou neutro em relação a processos sociais. Ele tem um papel central no processo de exclusão social e de segregação territorial, no entanto, pode ser ferramenta de transformação e reforma urbana, dependendo de como for mobilizado (FERNANDES, 2007).

A diversidade em si é instituída pautada na existência de uma norma, e essa é uma das primeiras contradições do Estado liberal-democrático referente à cidadania. Os Direitos e ideais supostamente universais são garantidos apenas para aqueles pertencentes à hegemonia. Os significantes 
vazios da lei somente adquirem existência concreta quando ocupados por conteúdo particular, e a hegemonia, quando colocada enquanto uma posição universal, é a única capaz de preencher (SABSAY, 2011).

Isto cria uma fronteira, em que de um lado estará a universalidade hegemônica, os corpos que importam, e do outro, os estigmatizados, abjetos (BUTLER, 2015). É possível perceber que existem normas implicadas na lei. A cidadania, por exemplo, pressupõe uma noção de subjetividade ancorada no alinhamento de diversos elementos, como gênero, orientação sexual, cor e classe específicos, sem que esteja expresso na redação, tornando-se mais complexa a crítica e negando essa exclusão (SABSAY, 2011).

A cidadania é algo dinâmico e passível de revisão, a ser definida pela conversação e negociação, para qual é imperioso o diálogo que reconstitui seus participantes de maneira significativa. Assim, a aceitação acrítica da concepção de cidadania não constitui a inclusão civil (MODOOD, 2008). Segundo Modood (2008), trata-se, portanto, não apenas do Direito a ser reconhecido, mas de questionar os termos desse reconhecimento, que deve compreender a heterogeneidade interior à comunidade.

Judith Butler (2015) entende a cidadania enquanto um processo social dinâmico, constituído e reconstituído no decorrer do intercâmbio social, impossível de ser singularizado ou multiplamente determinado. Isto porque "a cidade é vivenciada de forma diferenciada por seus moradores" (ALFONSIN, 2009 p. 254), logo, não há que se falar em neutralidade do planejamento urbano, pois este, quando assim realizado, privilegia certo grupo social que detém o acesso a bens materiais e simbólicos produzidos pela cidade.

Parte desse contexto é o limite de acesso à visibilidade, que reflete em uma paz visual, traduzida como tranquilidade pública. Logo, é preciso que a legislação parta da premissa do estado atual das relações sociais e da parcialidade das normas, o que faz surgir novos direitos e sujeitos de 
direitos, antes ocultos no cenário jurídico e político (SOUZA FILHO, 2010). A lei da cidade e a segregação sócio-espacial constituinte do cenário urbano brasileiro são reflexos um do outro e desconsiderar ou ignorar que esse espaço é utilizado e demandado de diversas formas a8penas aumenta a ineficiência de intervenções ou políticas públicas (ALFONSIN, 2009).

Políticas públicas não devem ser pensadas para uma massa homogênea. As pessoas têm sexualidade, gênero, contexto, história, e estão inseridas em relações de poder que impregnam e constituem toda a cultura da sociedade, e isso deve ser levado em consideração através de uma releitura da cidade (ALFONSIN, 2009). Somente o confronto constante das relações de poder pode fazer com que elas se invertam (FOUCAULT, 1988).

Isto não significa destituir a cidade de seu caráter ideológico, o que seria impossível porque a realidade urbana é permeada por essas relações, entretanto, deve-se enxergá-la sob outros olhares, re-centrados, compreendendo que ela não é produzida visando o coletivo, mas interesses individuais de determinados grupos (LEFEBVRE, 2001).

De acordo com Edésio Fernandes (2007), a ordem jurídica brasileira em vigor está em transição de um modelo de civilismo clássico - que estava em descompasso com processos socioeconômicos e territoriais do processo de urbanização brasileiro, pois não correspondia às necessidades de enfrentamento desse fenômeno e sua multidimensionalidade -, para o modelo que materializa a nova ordem jurídica urbanística.

Para ele, cabe a juristas compreenderem a extensão do papel do Direito na produção de um padrão excludente de urbanização. O legalismo liberal restringe o uso social por sobrepor o interesse individual ao coletivo e limitar a ação do poder público na determinação de uma ordem pública mais equilibrada e inclusiva. Novamente, entra em questão a omissão estatal que determina a exclusão de certos grupos sociais dos bens da cidade (FERNANDES, 2007) 
A tradição do legalismo, que insiste na neutralidade e a-historicidade do Direito, que seria um mero mecanismo de resolução de conflitos, aliado ao formalismo jurídico, tem reduzido o espaço de interpretação judicial progressista (FERNANDES, 2007). A forma tradicional de tutela desses Direitos era feita pela proteção de um Direito individual de cada habitante, no entanto, com o surgimento do Direito à cidade como um Direito fundamental, há sua reivindicação enquanto um Direito coletivo (SAULE JÚNIOR, 2005).

As condições ideais de identidade urbana, cidadania e pertença demandam uma política urbana coerente que, segundo Harvey (2014), está ameaçada pela ética neoliberal individualista, afastando-se do ideal de cidade enquanto corpo político coletivo, um local onde surgem movimentos sociais progressivos.

A respeito do Direito à cidade, cabe ressaltar a diferenciação estabelecida por Marcuse (2010), em contraste com a abordagem dada por Santos Junior (2014). Marcuse (2010) entende que há Direitos nas cidades e Direitos às cidades. Os primeiros seriam aqueles exigíveis e exercidos no âmbito da cidade, como o de moradia, meio ambiente equilibrado e mobilidade. Trata-se de Direitos parciais, com demanda específica a determinado grupo, assim, mesmo em consonância e alinhado ao Direito à cidade, são formulações diversas. Já a outra categoria de Direitos teria um caráter radical, que estende a demanda de mudança social para integrar uma visão de sociedade distinta.

Santos Júnior (2014), por outro lado, entende que esses Direitos, tidos como parciais por Marcuse (2010), estão abarcados como parte do Direito à cidade, constituindo componentes da agenda concreta de luta pela reforma urbana. Contudo, cabe ressaltar que o Direito à cidade não é a mera soma dessas aplicações e a inter-relação entre esses Direitos, mas o poder de influência e criatividade que os cidadãos têm sobre questões fundamentais da cidade em que vivem. Seu conteúdo deve ser "moldado 
pela perspectiva política, integrando-o ao poder de decidir e viver o espaço urbano a partir das demandas dos cidadãos" (GUIMARÃES, 2017, p.626).

Para Guimarães (2016), o Direito à cidade centraliza as demandas relacionadas a direitos sociais e difusos na vida urbana e sua interpretação deve ser extensiva para abarcar as dimensões política e social junto à jurídica, especialmente nesse momento em que os conceitos da lei estão em disputa e em construção. Esse Direito tem natureza difusa e é composto por outros direitos sociais e difusos, vinculado à dignidade da pessoa humana e regido pela solidariedade. Sua concretização demanda a atuação positiva do Estado, através de políticas públicas, não sendo sua natureza meramente programática (GUIMARÃES, 2016).

\subsection{Instrumentos que positivam o direito à cidade}

Um importante marco do Direito à cidade no âmbito internacional foi a edição da Carta Mundial do Direito à Cidade, que demonstrou o esforço de sistematização desse direito, embora haja resistências para sua efetivação. Ela se deu no âmbito do Fórum Social Mundial e trata dos Direitos Econômicos, Sociais, Culturais e ambientais da Cidade, concretizáveis através do sistema de participação direta, equitativa e deliberativa (SAULE JÚNIOR, 2005). Trata-se de um instrumento que busca fortalecer processos, reivindicações e lutas urbanas, através da articulação dos atores, públicos, sociais e privados, para a promoção, reconhecimento legal, implementação, regulação e prática desse novo Direito Humano, de acordo com o preâmbulo da Carta Mundial de Direito à Cidade.

Não se busca nesta pesquisa analisar todos os documentos internacionais que tratam da temática, mas identificar nesta Carta as

principais diretrizes concretizadas. Embora outra relevante referência anterior dessa internacionalização seja o Tratado "Por Cidades, Vilas e 
Povoados, Justos, Democráticos e Sustentáveis", elaborado na Conferência da Sociedade Civil sobre Meio Ambiente e Desenvolvimento, além da Agenda Habitat aprovada na Conferência Global sobre os Assentamentos Humanos das Nações Unidas, que se referiram ao Direito à Cidade, optouse por focar na Carta Mundial do Direito à Cidade por sua atualidade, repercussão, especificidade do tema e abordagem detalhada de seus aspectos em um único documento, em vez de normas esparsas.

O documento busca a construção de cidades justas, humanas, democráticas e sustentáveis, a partir da constatação de que elas não oferecem condições e oportunidades equitativas aos habitantes para a satisfação de suas necessidades básicas. O preâmbulo infere que a população urbana, por suas características econômicas, sociais, culturais, étnicas, de gênero e idade, não têm seus Direitos mais básicos materializados por políticas públicas, que muitas vezes desconsideram essas características e os processos de produção popular para a construção das cidades e cidadania, resultando na deterioração da convivência social e na segregação territorial.

Nela, o Direito à cidade é tido como interdependente de todos os Direitos Humanos internacionalmente reconhecidos, de forma integral e indivisível:

Art. I, 2: 2. O Direito a Cidade é definido como o usufruto eqüitativo das cidades dentro dos princípios de sustentabilidade, democracia, equidade e justiça social. É um direito coletivo dos habitantes das cidades, em especial dos grupos vulneráveis e desfavorecidos, que lhes confere legitimidade de ação e organização, baseado em seus usos e costumes, com o objetivo de alcançar o pleno exercício do direito à livre autodeterminação e a um padrão de vida adequado. O Direito à Cidade é interdependente a todos os direitos humanos internacionalmente reconhecidos, concebidos integralmente, e inclui, portanto, todos os direitos civis, políticos, econômicos, sociais, culturais e ambientais que já estão regulamentados nos tratados internacionais de direitos humanos (Carta Mundial do Direito à Cidade).

A cidade é vista, na Carta, enquanto um espaço coletivo culturalmente rico e diversificado, pertencente a todos os seus habitantes. O 
Direito à cidade deve ser exercido sem discriminação de gênero, idade, raça, etnia, orientação política e religiosa, preservando a memória e a identidade cultural (SAULE JÚNIOR, 2005). Como princípios são elencados a gestão democrática da cidade, a função social da cidade, a função social da propriedade, o exercício pleno da cidadania, a igualdade e não discriminação, proteção especial de grupos e pessoas vulneráveis, compromisso social do setor privado, e o Impulso à economia solidária e a políticas impositivas e progressivas. Neles devem ser baseadas as políticas urbanas a serem implementadas.

Um dos princípios basilares do Direito à Cidade, que é também um meio para a concretização dos demais, é o da gestão democrática da cidade, efetivada a partir de um sistema de participação direta, equitativa e deliberativa (SAULE JÚNIOR, 2005). Consoante a ele, deve-se fortalecer o papel dos municípios, para que se descentralize e especifique as políticas urbanas de acordo com o cenário, para a promoção de políticas públicas que assegurem os direitos dos habitantes mediante a participação popular dos segmentos em situação de desigualdade econômica e social. Trata-se de uma forma de planejar, produzir, operar e governar as cidades, com participação da sociedade civil, elencando como prioritários a autonomia dos poderes públicos locais e a participação popular (SAULE JÚNIOR, 2005).

A Carta reconhece a plena exigibilidade do Direito à cidade, instituindo que constituem lesões a esse Direito tanto ações quanto omissões que resultem em recusa, dificuldade ou impossibilidade de realização dos Direitos estabelecidos nela. Ela seria uma cartilha para guiar a construção de cidades justas, humanas, democráticas e sustentáveis, permitindo a participação da população no planejamento, produção e gestão da cidade (DUARTE, 2015), além de uma referência política, social, econômica e ambiental para políticas públicas e movimentos sociais (OSORIO, 2005). 
Assim, embora não haja um estatuto internacional que garanta $o$ direito à cidade, há normas que garantem Direitos mais específicos, contidos no conceito de Direito à cidade, reforçando a necessidade de sua aplicabilidade (OSORIO, 2006). A obrigatoriedade do Estado em efetivar esses direitos não é apenas moral, mas jurídica, que tem por fundamento tratados internacionais de Direitos Humanos, principalmente o Pacto Internacional dos Direitos Econômicos, Sociais e Culturais (PIOVESAN, 2004). Reitera-se sua importância também por representarem, a partir da vulnerabilidade econômico-social, a violação dos direitos civis e políticos, pela indivisibilidade dos direitos humanos (PIOVESAN 2004).

Apesar de ter ratificado em 2005 a Carta Mundial do Direito à Cidade e participado de fóruns internacionais que debateram a temática, o Brasil ainda está distante de concretizar o Direito à cidade ou instituir suas normativas no ordenamento jurídico brasileiro de forma efetiva. No âmbito interno essas formulações vêm sendo implementadas a partir da Constituição Federal e o Estatuto da Cidade, com muitas dificuldades para sua real concretização.

O processo de urbanização brasileiro, diante da lógica da industrialização, começou no início do século XX, teve seu auge na década de 1970 e se firmou enquanto um desenvolvimento informal que ocasionou a natureza elitista e tecnocrática do planejamento urbano em diversas cidades (FERNANDES, 2010). A Constituição Federal de 1988 é a primeira a trazer um capítulo sobre política urbana (art. 182 e 183) e, embora não mencione expressamente o Direito à Cidade, proporcionou bases jurídico-políticas para tal. Esse capítulo foi escrito a partir da emenda popular de reforma urbana, formulada e assinada por mais de 100 mil organizações sociais e indivíduos que participavam do movimento nacional de reforma urbana (FERNANDES, 2010).

As reivindicações encaminhadas pela emenda foram quase integralmente aprovadas, no entanto, diante da impossibilidade de aprovar uma fórmula constitucional mais progressista em determinados aspectos 
dela, optou-se por "subverter" o uso de dispositivos aprovados para que fosse realizado um investimento consciente dos atores envolvidos na edição de planos diretores municipais includentes e participativos. Isto é, Instrumentos que permitissem a gestão democrática da cidade, assim como a adoção de conceito de funções sociais da cidade estão presentes na Constituição, possibilitando uma nova visão do processo de urbanização e a distribuição dos ônus e benefícios a ele inerentes (FERNANDES, 2010).

Alguns autores, como Santilli (2006) identificam a Constituição Federal como a inauguração de "novos direitos" ao romper com paradigmas da dogmática jurídica tradicional, libertando-se do formalismo excessivo, da falsa neutralidade política e científica, da ênfase nos direitos individuais, patrimoniais e contratualista e de inspiração liberal. Eles teriam natureza emancipatória, pluralista, coletiva e indivisível, constituindo desafios à ciência jurídica no âmbito conceitual e doutrinário, como também à sua concretização, transcenderiam o dualismo público-privado, estando em um escopo público não-estatal, classificados como direitos de terceira dimensão ${ }^{9}$, por representarem uma titularidade coletiva (SANTILLI, 2006). Entendem, portanto, que essa dimensão enquadraria direitos de natureza metaindividual, difusa e coletiva, seriam direitos de solidariedade, como o direito ambiental, por exemplo (SANTILLI, 2006).

Ademais, diz-se que a Constituição Federal de 1988 consagrou o marco epistêmico e metodológico do Pluralismo jurídico. Wolkmer (2001) entende que fora consagrado o valor da diversidade e da emancipação ao legitimar a convivência e coexistência de concepções divergentes. À medida que a sociedade é vista enquanto um sistema conflituoso, tenso e de constante transformação, apenas identificando os fatores de mudança que levam à constante inadequação de modelos culturais tradicional, dentre eles,

\footnotetext{
${ }^{9}$ Os Direitos de primeira dimensão são os civis e políticos, de natureza individual; os de segunda são os sociais, econômicos e culturais. As "dimensões" eram chamadas, anteriormente, de "gerações", entretanto, a teoria passou a ser criticada pela doutrina por induzir ao equívoco de um processo substitutivo. Atualmente, diante da percepção de que eles se somam e complementam, alterou-se chama-se de "dimensões" de Direito (SANTILLI, 2006).
} 
o Direito, haverá uma análise que pode ser considerada válida (WOLKMER, 2001).

O padrão de cientificidade que sustenta o discurso da legalidade "liberal-individualista/formal-positivista" se demonstrou desajustado pelas contradições sociais e as facetas de produção do capital globalizado. Isto impôs a rediscussão dos fundamentos, fontes e objetos do Direito (WOLKMER, 2001).

O Pluralismo no Direito permitiria a produção e aplicação normativa descentralizada e participativa, um sistema difuso de "poderes emanados dialeticamente da sociedade, de seus diversos sujeitos, grupos sociais, coletividades ou corpos intermediários" (WOLKMER, 2011, p. 145). Ele pressupõe "fenômenos autônomos e elementos heterogêneos que não se reduzem entre si" (WOLKMER, 2001, p. 172), um deslocamento do Estado para a sociedade, uma dinâmica mais interativa (WOLKMER, 2001).

A Constituição de 1988, portanto, é tida, por parte da doutrina, como um instrumento diretivo propulsor para esse novo constitucionalismo, pluralista e multicultural, paradigma este em que se encontra o Direito à cidade. No entanto, é possível perceber que as bases constitucionais e as leis infraconstitucionais, apesar de construídas a partir de processos democráticos não possibilitaram que a cidadania fosse exercida por todxs, não foi possível alcançar esse novo paradigma colocado por esses doutrinadores mencionados. Ela ainda é pautada pela neutralidade e não percepção da heterogeneidade e especificidades necessárias que compõem a população.

Como resultado de um intenso processo de negociações dentro e fora do Congresso Nacional, foi editado o Estatuto da Cidade (Lei Federal $n^{o}$ 10.527/2001), que reconhece explicitamente o Direito à Cidade no Ordenamento Jurídico brasileiro, como a "garantia do direito a cidades sustentáveis, entendido como o direito à terra urbana, à moradia, ao saneamento ambiental, à infraestrutura urbana, ao transporte e aos serviços 
públicos, ao trabalho e ao lazer, para as presentes e futuras gerações" (artigo $2^{\circ}$, caput e inciso I).

Ao interpretar o tratamento jurídico brasileiro, CAVALLAZZI (2007) entende o direito à cidade como expressão do direito à dignidade da pessoa humana, o núcleo de um sistema composto por um feixe de direitos que inclui o direito à moradia implícita a regularização fundiária -, à educação, ao trabalho, à saúde, aos serviços públicos - implícito o saneamento -, ao lazer, à segurança, ao transporte público, à preservação do patrimônio cultural, histórico e paisagístico, ao meio ambiente natural e construído equilibrado - implícita a garantia do direito às cidades sustentáveis como direito humano na categoria dos interesses difusos (GUIMARÃES, 2016, p. 45).

Era imperioso, para efeitos concretos, a elaboração de diretrizes gerais de direito urbanístico e normas que consagrassem instrumentos importantes para sua operatividade (SUNDFELD, 2008). Um papel relevante da nova lei foi afastar certas construções da legislação tradicional civil e administrativa, incompatíveis com as novas soluções do Direito urbanístico.

Com ele, é firmado e ampliado o papel dos Municípios na formulação das diretrizes de planejamento urbano e na condução dos processos de gestão urbana (FERNANDES, 2010), contribuindo para um paradigma político jurídico diverso da tradição do civilismo jurídico já referido e desenvolvendo o princípio constitucional da função social da cidade, que substitui o individualista do Código Civil de 1916 (FERNANDES, 2010).

Como legitimação dessa nova ordem jurídico-urbanística, o Estatuto da Cidade institui diversos processos para que os Municípios integrem planejamento, gestão e legislação urbana de modo a democratizar as decisões locais, para que se possibilite a participação efetiva da sociedade, através de, por exemplo, audiências, consultas e da criação de conselhos. Além de Municípios com mais de 200 mil habitantes, dentre outros requisitos, terem que aprovar seus planos diretores em até 5 anos após a 
promulgação da referida lei, ela tem sido complementada por importantes normativas em consonância com esse movimento de reforma jurídica, com destaque para a criação do Ministério das cidades em 2003 (FERNANDES, 2010). Entretanto, até a presente data, a expressão de tais instrumentos tem sido ínfima.

É preciso que se desvincule do processo de criação de leis e planejamento da cidade a ideia de que conhecimento que não é científico não é válido. Também não se legitima nesse processo, formas simbólicas de comunicação, impossibilitando a escuta de muitos segmentos da população. Não há planejamento urbano puramente técnico, geral, abstrato, incorpóreo ou que abarque a todxs (BERNER; MELINO, 2016). Admitir que há uma perspectiva significa negar o mito da racionalidade técnica $\mathrm{e}$ da neutralidade, na qual muitos planejadores se baseiam, o que pode levar a muitos questionamentos por parte de juristas que buscam eternizar conhecimentos globais, em vez de preocupar-se com o que os cercam (BERNER; MELINO, 2016).

Teóricos descoloniais destinam-se a, em vez de incorporarem soluções prontas e fechadas para problemas vividos, contextualizar social, cultural e politicamente nos países periféricos o que se produziu à margem do conhecimento hegemônico por imposição de processos civilizatórios colonizadores (BERNER; MELINO, 2016).

Descolonizar seria recuperar o humano para além de uma supremacia hegemônica e uma inferioridade de sujeitos abjetos (FANON, 2008). Eles buscam entender e localizar experiências, produzindo novos formatos ao passo em que compreendem o contexto em que a subordinação é produzida. O objetivo é re-centrar o debate, mover-se para além do enquadramento que presume uma oposição e exclui diversas dimensões para mudar os termos impostos por aquelxs detentorxs do poder-saber (BUTLER, 2015). 
Essa necessidade de mudança de perspectiva é para complexificar o processo e não o simplificar, inclusive porque não é apenas a perspectiva LGBTI+ que está sendo apagada, mas de todos os grupos marginalizados. Mesmo com a descentralização do planejamento urbano e aumento da participação dos municípios, não se enxerga essa mudança uma vez que as massas, exatamente essa parte da população que é marginalizada, não têm o mesmo peso político. Embora haja alguns instrumentos, prevalece o pensamento neoliberal (BERNER; MELINO, 2016). O "conflito", elemento constitutivo da cidade deve ocorrer entre pessoas que se reconheçam iguais. Em vez de conflito, o que aparece na cidade é o falso consenso.

Esses sujeitos, que não têm o mesmo peso político, em uma gestão democrática, devem se organizar em coletividades para pressionar o Estado a atender suas reivindicações. Esse grupo que, por um lado é homogêneo pela precariedade urbana, mas ao mesmo tempo heterogêneo em sua composição, têm grandes dificuldades de conseguir a efetivação de seus Direitos (BERNER; MELINO, 2016).

\subsection{Espaços públicos e a produção do não-lugar}

O não-lugar desumaniza, é um fracionamento que não desmonta por completo, que condiz com o projeto urbano em que se pretende a transitoriedade de corpos e menos a experiência entre pessoas (MARCONDES, 2017). O espaço público é onde ocorre a troca de experiências entre pessoas e grupos, onde pode ser consagrada essa experiência, os encontros, cenário de conteúdo histórico comum. Todavia, para pessoas LGBTI+, o entendimento é que os espaços públicos não são deles, ao contrário, por diversas violências se demonstra que esse não é seu lugar. É possível perceber que essas violências não se dão de forma homogênea, mas geram insegurança em diferentes graus dependendo do 
local em que estiver e de sua performatividade. Em entrevista com a revista brejeiras (2018), Monica Benício, mulher lésbica cisgênero, afirmou:

\begin{abstract}
O risco da violência era o que eu achava mais grave de assumir a orientação sexual dentro da favela. Uma coisa que eu entendi com a minha vivência na Maré foi que é diferente ser lésbica "estereotipada" sapatão e ser uma lésbica lida como feminina, no estereótipo da "boneca". Ser a "boneca" traz o perigo de quando as pessoas descobrem a sua sexualidade, não levam a sério. Ficam com aquela coisa "ah, mas é porque você nunca encontrou um piru bom ou ninguém nunca te comeu direito". Eu já ouvi esse tipo de colocação de amigos. Você se percebe vulnerável a um estupro corretivo, por exemplo. É aquela coisa "vou te mostrar o quão bom macho eu sou e aí você vai parar com essa palhaçada, porque você é mulher". (...) Levando em consideração que o asfalto que eu frequentei, em boa parte da minha vida, foi a zona sul do Rio de Janeiro, por questão da PUC, era bem mais fácil. Então, afirmar ser sapatão era um ato político (BREJEIRAS, 2018, p. 15-16)
\end{abstract}

Espera-se de uma parte da sociedade que se atenha a determinados espaços sociais. Quando essas pessoas "inapropriadas” saem de seu local, o “olhar imperial” busca retorná-lo à posição "natural”, à zona do não-ser. Isso ocorre através de violências simbólicas e físicas. Elas serão lembradas de sua posição periférica de maneiras aparentemente sutis (FANON, 2008). Dar visibilidade a um corpo antes invisibilizado é um ato que em si propõe a reestruturação social, envolve a negação da clivagem entre essas duas zonas. Afirmar a visibilidade do invisível é simultaneamente afirmar aqueles que estão na zona do não ser e os da zona do ser, afirmar o corpo enquanto agência de intervenção política e intelectual (FANON, 2008).

A necessidade de regulamentação do desejo tem reflexos no espaço público em função da necessidade de garantia da estabilidade desses parâmetros para se pensar a cidadania (SABSAY, 2011). A título de manutenção do imaginário sexual criado, a sexualidade foi colocada enquanto assunto privado, que a esse âmbito deve se limitar. Trata-se de um medo da potencialidade de desestabilização criada pelo poder de imagens, e o ensinamento de outras sexualidades, gêneros e práticas sexuais que entrassem no campo de visão como "normais". 
A ordem da cis-heteronormatividade seria mantida pela pura e exclusiva repetição de suas normas e práticas (SABSAY, 2011). Observa-se isto no medo de que crianças sejam exposta a pessoas LGBTI+, de perguntarem sobre, de filmes que não podem retratar a temática, a presença ínfima na mídia. A diversidade de gênero e sexual é considerada algo contra a instituição à família, que deve se restringir ao espaço íntimo, ao privado, escondido, é algo imoral, pois representa um risco aos processos de subjetivação hegemônicos. Ocupar o espaço público para esses corpos já é em si transgressor.

A diversidade incomoda, e a solução simbólica foi retirá-los de uma zona em que se apresentam como ameaça visual, em que violam um campo visual supostamente legítimo (SABSAY, 2011). A partir da criação do imaginário de restrição desses corpos, sua performatividade e troca de afetos a espaços privados, a cidade passa a ser para muitxs uma "cidade armário", segundo Didier Eribon (2008). Um dos princípios estruturantes das subjetividades LGBTI+ é a procura por formas de fugir de injúrias e violências do cotidiano, normalmente, através da dissimulação de si mesmo, ou migração para lugares mais clementes (ERIBON, 2008). Reações fóbicas vêm de um medo irracional, de uma fantasia que é produzida, um mecanismo de um estado psicossocial onde o poder regulador trabalha (SABSAY, 2011).

De acordo com Goffman (1975), a categoria estigmatizada busca dissimular o seu "defeito", tendo que estar constantemente atento à situação social, tornando-se estranho ao mundo que o cerca, pois novos perigos surgem, não sendo mais adequada a camuflagem anterior. Isto gera uma tensão que pode deixar suas marcas na personalidade individual (GOFFMAN, 1968). O armário confere apenas uma segurança incerta, mesmo nele pode-se estar exposto a comentários, boatos, insinuações e brincadeiras. (GOFFMAN, 1968).

Grave consequência disto é que essa estrutura de dominação é marcada nxs dominadxs de forma que até eles as utilizam, não sabendo que 
serão mais tarde destinatários, ou sabendo, e a utilizam por ser uma forma de se precaver contra isso. O ódio de si pode acabar sendo interiorizado, pois a constituição da subjetividade se dá ao mesmo tempo em que presencia essas injúrias e estigmas (ERIBON, 2008).

Apesar de uma história singular, ela se confunde com a coletiva, pelos processos de inferiorização. O pertencimento aceito e assumido permite que o sujeito tenha sua própria história, tendo que constituir sua nova linguagem, maneira de falar, modelos de apresentação de si (ERIBON, 2008). Isto porque suas atitudes estavam sempre enraizadas em um ambiente inseguro em que se temia a identificação (GOFFMAN, 1968).

Ochy Curiel (2013) chama de sexílio, quando, em regimes políticos repressivos e em busca de amor, liberdade e melhores oportunidades, pessoas LGBTI+ migram para não permanecerem com limites de possibilidades sociais, convivências e acesso a bens materiais, como saúde, moradia e emprego. De acordo com a pesquisa de Camila Esguerra, antropóloga colombiana que estudou a motivação da migração de lésbicas latino-americanas, o principal motivo para esse deslocamento constitui a liberdade e a saída da invisibilização que se assume por medo, controle ou perseguição familiar e social em seu país de origem (CURIEL, 2013). Como já mencionado antes, até esconder-se no armário não é opção de todxs LGBTI+.

Nas ruas pelas surdinas é onde faz o seu salário

Aluga o corpo a pobre, rico, endividado, milionário

Não tem Deus

Nem pátria amada

Nem marido

Nem patrão

O medo aqui não faz parte do seu vil vocabulário

Ela é tão singular

Só se contenta com plurais

Ela não quer pau

Ela quer paz (MC LINN DA QUEBRADA, 2017) 
Dentro desse cenário há também a disputa sobre o que é violência, pois nem todas são legitimadas. Sua legitimidade muitas vezes recai sobre se a pessoa é considerada humana, se é um sujeito inteligível (SABSAY, 2011). A violência simbólica, de sequestro de memória, e física, mais direta e impactante, muitas vezes têm respostas midiáticas ou jurídicas e, nesse ciclo ininterrupto, acaba-se não percebendo que a violência se reproduz em todos, não só em algumxs; e esses espaços de pouca convivência e grande circulação levam ao esquecimento da própria história. O apagamento da memória torna o sujeito mais psicologicamente vulnerável e, portanto, mais propenso a sofrer violência.

A criação do não-lugar na cidade seda a percepção das violências, não há sequer tempo para compartilhar histórias e memórias nesse espaço (MARCONDES, 2017). Isto é particularmente relevante no caso de pessoas LGBTI+, pois ao tratar-se de uma diferença horizontal, ou seja, não é uma herança familiar, mas algo que destoa de seus parentes, a própria casa não é um espaço de acolhimento, assim, muitas vezes podem ser violentados ou expulsos desse espaço também (SOLOMON, 2012):

De onde eu vim, é fome e medo de ficar na mesma

Não caber na própria casa

Sai pro mundo e não cabe no mundo

Não cabe em verso cada tapa, momentos, fraqueza

Muitos anos de revolta desse jogo sujo

Não é guerra do sexo, homofobia chama (QUEBRADA QUEER, 2018)

Demonstração desse não-lugar é também o que tange a memória. A falta de informação sólida e dados sobre as condições de vida desses segmentos nas áreas de saúde, segurança, quantificando a violência de pessoas LGBTI+, é uma forma de violência por si só, pois significa a impossibilidade de realizar políticas públicas e o apagamento dessas experiências vividas (MARCONDES, 2017).

Não entra em conta no planejamento público pensar no estupro corretivo, nos ataques de ácido, na entrega forçada a "hospitais" de 
conversão da sexualidade, pensar na segurança pública para pessoas trans que são frequentemente expulsas de locais e espancadas, a dificuldade de empregabilidade que levam muitas à prostituição ou estarem em situação de rua, sequer em pensar canais de denúncia mais efetivos em que não haverá o medo de represália, ou na exclusão que os levam a estarem mais vulneráveis a ter depressão, transtornos alimentares ou cometer suicídio. Esse cenário leva ao medo e insegurança na cidade, que muitas vezes pode ser o único espaço de pessoas LGBTI+.

Isto se manifesta também pela ausência de espaços oficiais que preservem sua cultura e história. Sua visibilidade ameaça a ordem, o interrelacionamento historicamente variável de pessoas LGBTI+ e pessoas cisgênero e heterossexuais, a sua força constitutiva recíproca e um terreno comum entre elxs, é algo preferível esconder (SCOTT, 1998).

Com relação a espaços oficiais, um exemplo é a revolta no Ferro"s bar de São Paulo, também chamada de Stonewall ${ }^{10}$ brasileiro. Em 1983, ocorreu um protesto neste bar, majoritariamente frequentado por mulheres bissexuais e lésbicas. Frequentadoras do estabelecimento foram impedidas, durante a Ditadura Militar, de vender o zine "chana com chana", panfletos de luta e liberdade sexual, e foram expulsas de forma violenta. Elas resistiram, sendo apoiadas pelas demais mulheres do bar. A polícia permitiu que permanecessem lá extraordinariamente, desde que o material não fosse distribuído nos próximos dias. Segundo Mariam Martinho, coordenadora do grupo "Um Outro Olhar", grupo de militância LGBTI+, vendia-se até substâncias ilícitas lá, mas a publicação lésbica em um bar sustentado por lésbicas não poderia circular (NOSSO AMOR EXISTE, 2016).

O levante ocorreu em agosto, resultando no pedido de desculpas do dono do bar, a liberação da venda dos panfletos, e culminou na consagração do dia 29 de agosto como dia da visibilidade lésbica. Ocorre que, hoje, o espaço físico desse bar tornou-se um restaurante como outro qualquer, o

10 A rebelião de Stonewall foi uma manifestação em Nova York, no bar Stonewall Inn, em reação à repressão policial ao público LGBTI+, que ocorreu em 28 de junho, data em que hoje se comemora o Dia do Orgulho LGBTI+ 
que demonstra a desimportância política que se dá à preservação dessa memória (MARCONDES, 2017). O desaparecimento gradual de espaços coletivos, apagamento de experiências vividas e transformação disso em fluxo de mão-de-obra, constata mais uma faceta da desumanização da cidade para certos corpos (MARCONDES, 2017).

Com as eleições de 2018, o cenário se tornou ainda mais preocupante para pessoas LGBTI+, com perspectivas ainda piores para o mandato do presidente eleito, Jair Bolsonaro. Depois do primeiro turno, o Disque 100, número de denúncia para vítimas LGBTI+, registrou um aumento em denúncias de $26 \%$, todas fazendo menção ao nome do eleito (SAMPAIO, 2018). O número de denúncias por esse telefone é muito aquém da realidade, mas demonstra o panorama em que a LGBTI+fobia, às vezes quase invisível a quem não a sofre ou não busca percebe-la, já referida, se torna discurso e atos discriminatórios diretos e com mais permissibilidade a partir de certo momento. A insegurança se torna tão grande, que muitas vezes a escolha é de sequer sair de casa, o circular na cidade resta extremamente prejudicado.

O Grupo Gay da Bahia registrou 346 mortes de LGBTI+ por crime de ódio até outubro de 2018, número que somente cresceu com as eleições. Segundo reportagem de 11 de outubro, o jornalista, Haroldo Ceravolo, mapeou 50 casos de violência cometidos desde o início do mês por defensores do candidato à presidência, Jair Bolsonaro. Nesse período, se tornaram comuns reportagens como "travesti é assassinada sob gritos de bolsonaro presidente" (CRUZ, 2018), "mulher trans é espancada com barra de ferro" (CRUZ, 2018), "homossexual morto por eleitor de bolsonaro" (Notícias ao Minuto, 2018). Julyana, uma mulher trans foi espancada por tentar argumentar com um ambulante que gritava "Bolsonaro vai ganhar para acabar com os veados, essa gente lixo tem que morrer" (VALLEDA, 2018). Nessa conjuntura, pessoas passam a ser ameaçadas com mais constância na rua, surgem muitas pichações homofóbicas em cidades (G1, 2018), e muitxs políticxs incitam crimes por discursos ou atitudes como a 
do governador eleito, Wilson Witzel que, ainda durante as eleições, quebrou a placa de rua (ISTOÉ, 2018)produzida em homenagem a Marielle Franco, mulher negra bissexual, ex-vereadora do Rio de Janeiro, assassinada no mesmo ano, que foi considerado um crime político por muitos, inclusive pelo atual procurador-geral de justiça do Rio de Janeiro, Eduardo Gussem (FOULART, 2018).

O futuro governador postou em redes sociais um vídeo com a placa cortada em pedaços, junto a Rodrigo Amorim, ex-candidato a vice-prefeito do Rio de Janeiro em 2016 em chapa de Flávio Bolsonaro, que afirmou estar "cumprindo dever cívico", declarando: "preparem-se esquerdopatas: no depender de nós, seus dias estão contados" (ISTOÉ, 2018). Wilson Witzel tem um filho trans, Erick, e buscou usá-lo, alegando que o mesmo concordava com sua política e postura, que "conviviam bem". Erick informou, posteriormente, assim como antes já havia se manifestado nesse sentido, que se opunha a seus direcionamentos e reprovava sua campanha e que pessoas LGBTI+ podem ser prejudicadas com seu governo (ARAÚJO, 2018). A manifestação de seu pai, inclusive, fez com que ele fosse ainda mais "marcado" como uma pessoa trans.

Foi criado um jogo online denominado "Bolsomito 2K18", no qual um personagem que imita o então presidenciável, Jair Bolsonaro precisa "derrotar os males do comunismo", "inspirado no atual momento político brasileiro", tendo como tarefa a eliminação violenta da vida de pessoas LGBTI+, negras, mulheres, militantes do movimento sem-terra, petistas e outrxs candidatxs das eleições de 2018 que, quando agredidxs se transformam em fezes (HMC, 2018a).

Essas notícias revelam a onda de medo instaurada com o período eleitoral, que tende a piorar durante os governos que têm início em 2019. O Presidente da República eleito já se manifestou negativamente diversas vezes com relação à diversidade de gênero e sexual. Além de não mencionar direitos LGBTI+ em seu plano de governo, ele se comprometeu a barrar avanços do movimento em e busca reconhecer apenas o casamento 
heterossexual (HMC, 2018b). Maria Berenice Dias, desembargadora presidenta da Comissão da Diversidade sexual da Ordem dos Advogados do Brasil (OAB) recomendou que, diante da ameaça simbolizada por Bolsonaro, casais LGBTI+ que desejam se casar em um futuro próximo, se antecipem até o fim do ano de $2018^{11}$.

Diante da prova do ENEM, que utilizou em questão de interpretação de texto referências ao pajubá, dialeto secreto com expressões provenientes de línguas africanas utilizado por pessoas LGBTI+ durante a ditadura militar, Jair Bolsonaro se pronunciou garantindo que não haverá perguntas com “ideologia de gênero" no próximo exame (PATI, 2018).

A Comissão Interamericana de Direitos Humanos (CIDH) realizou uma visita in loco no Brasil, nos dias 5 a 12 de novembro de 2018, e produziu um documento com observações preliminares. Dentre os pontos ressaltados estava o discurso de incitação ao ódio e à discriminação, em que se pontuou que comentários em redes sociais proveem ou são habilitados por candidatxs a cargos políticos eletivos ou funcionárixs públicos. Segundo a CIDH, esse tipo de expressão daria permissibilidade ao exercício de violência por grupos que adotam discursos homofóbicos ${ }^{12}$, racistas e misóginos. Ela enfatizou a necessidade de funcionárixs públicxs adotarem discursos públicos que contribuam para a prevenção da violência, não sua incitação.

Cabe ressaltar que o artigo 13.5 da Convenção Americana, ratificada pelo Brasil, institui a apologia ao ódio nacional, racial ou religioso que incite violência ou ações ilegais contra qualquer grupo de pessoas. Segundo o documento, a Comissão e sua Relatoria Especial entendem que à luz dos princípios gerais da interpretação dos tratados, inclui-se nessa proibição ações que discriminem por motivo de orientação sexual, identidade de gênero ou diversidade corporal, assim como qualquer atitude similar.

\footnotetext{
${ }^{11}$ Esse entendimento não é de todxs xs membros da comissão, tendo sido criticado por alguns delxs.

12 termo utilizado pela CIDH em seu relatório.
} 
Perante a mesma convenção o Estado brasileiro obrigou-se, ademais, a investigar as violações de direitos humanos de maneira adequada, eficaz e oportuna. De acordo com o Grupo Gay da Bahia, ficam impunes 70\% dos assassinatos a pessoas LGBTI+ no Brasil.

Foi recomendado pela $\mathrm{CIDH}$, com relação a medidas de combate à discriminação, medidas afirmativas que garantam a efetiva igualdade perante a lei de todxs, principalmente aquelxs que sofrem desigualdades estruturais ou processos históricos de exclusão. Com relação a discurso de ódio, que o Estado garanta uma legislação sancionadora, uma vez que constitui incitamento à violência com motivação discriminatória, diante de padrões da Convenção Americana sobre Direitos Humanos e diretrizes da Comissão e Corte Interamericana.

A LGBTI+fobia mata e não pode ser tratada apenas igualando direitos civis - o que sequer foi feito na legislação -, mas com a atenção a fatos e opressões específicas que perpetuam a LGBTI+fobia estrutural, que permeia diversos direitos, e influenciam diretamente em como esse grupo social vive a cidade. 


\section{CAPÍTULO 3: A cidade como espaço de luta e o lazer social, ferramenta de humanização da área urbana}

Diante do cenário descrito, a cidade é transformada em um lugar inóspito, não sendo possível o prazer, que será adstrito a espaços, tempos e corpos determinados. A cidade moderna é fortemente associada à ideia de circular livremente, no entanto, ela sempre foi regulada. O controle dos movimentos em público é constantemente uma preocupação de governantes e de segurança. Em grande parte, esse circular é um privilégio, limitado a protagonistas que pertençam a um determinado grupo, em geral, homem branco cisgênero, heterossexual, proprietário e cristão. Busca-se manter uma ordem que muitas vezes não inclui a existência de pessoas que não se adequem a uma determinada regra.

Quando a repressão policial não permite sair, não investigar crimes também leva ao aumento da criminalidade com relação a elxs. Assim, o circular torna-se inviável para muitxs LGBTI+, que se sentem constantemente ameaçadxs e não à vontade. Para alguns, a cidade tem que ser conquistada, pois a sua presença em si já é transgressora. utilizar o espaço público sem ser como trajeto é enfrentar diversas dificuldade. Aqui, busca-se analisar o lazer e suas conexões com a cidade, a partir da lente da cis-heteronormatividade.

\subsection{A acessibilidade a equipamentos de lazer}

Para conceituar o lazer, atualmente, não é possível identificá-lo enquanto oposição ao trabalho simplesmente ou algo que não demanda empenho ou esforço. Não se trata mais uma vivência simples, redutível ao consumo de mercadorias de prazer (ROLNIK, 2000). Apesar de anteriormente ser reservado a privilegiadxs, o lazer passou a ser para todxs, primeiro como possibilidade, depois reivindicação e, hoje, como uma 
necessidade real (DUMAZEDIER, 1976). Isto também diante do crescente interesse da sociedade nele, à medida que o capitalismo se consolidava.

A experiência do lazer é dificilmente desvinculada da urbanização e indústria do lazer, que produz uma universalidade de como exercê-lo. No Brasil, o conceito mais amplamente utilizado por autores é o do sociólogo Joffre Dumazedier (1976):

O lazer é um conjunto de ocupações às quais o indivíduo pode entregar-se de livre vontade, seja para repousar, seja para divertir-se, recrear-se ou entreter- se ou, ainda para desenvolver sua informação ou formação desinteressada, sua participação social voluntária ou sua livre capacidade criadora após livrar-se ou desembaraçar-se das obrigações profissionais, familiares e sociais. (DUMAZEDIER, Joffre, 1976, p. 34)

É possível identificar nesse conceito alguns elementos que restam prejudicados para muitxs. Primeiramente, a liberdade de escolha, que pode ser comprometida pela falta de oportunidade, de disponibilidade de opções, pelo acesso a tempo livre, ao ócio que permita que haja uma escolha (LOPES, 2017), mas também pela sensação de insegurança que limita a maioria dos ambientes como opção.

Alguém que seja LGBTI+ deveria poder optar por exercer seu lazer em qualquer ambiente ou espaço que queira, não se restringindo e permanecendo em grupos, para ter o elemento de liberdade de escolha respeitado. Outro elemento relevante são as funções do lazer, suas contribuições para o processo social do indivíduo, como o descanso, divertimento e desenvolvimento. O descanso seria livrar-se da fadiga, repondo forças físicas e mentais. Centros urbanos podem ocasionar muito desgaste, principalmente quando os ambientes não são seguros para transitar, o papel do lazer seria trazer uma tranquilidade e relaxamento, mesmo em uma atividade agitada (LOPES, 2017)

O divertimento seria a capacidade de distração, o preenchimento do tempo de forma alegre e prazerosa, uma satisfação pela mudança de direção, um meio de suportar obrigações diárias pela evasão temporária do 
universo cotidiano. O desenvolvimento da personalidade seria proporcionar o crescimento do indivíduo pela participação social maior e mais livre, juntando-se a grupos em que ocorresse uma maior interação social (DUMAZEDIER, 1976).

A interação, assim como outras formas de vivência lúdica, possibilitaria a criação de novas formas de aprendizagem, conduta, enriquecimento da personalidade, desenvolvimento de humanidade, segundo Dumazedier (1976). Outras situações, como o trabalho, também poderiam proporcionar essa interação, mas o resultado é outro. Pessoas LGBTI+ em contato com outrxs, acabam conseguindo se entender muito mais, por estarem experienciando vivências que não são expostas pela mídia e muitas vezes contrárias ao que se aprendeu no ensino formal e informal.

Em sua maioria, a vivência do lazer é atravessada e alterada pela forma como o sistema capitalista se desenvolve, constituindo um nicho do mercado. A indústria cultural passa a ter influência e direcionar o lazer e as formas das pessoas se relacionarem (LOPES, 2017). Indústria cultural e do entretenimento serão aqui utilizadas enquanto produção simbólica relacionada ao setor da vida cultural, assim como o mercado, a atuação das empresas, que transforma os lazeres em produtos. Elas corroboram sensivelmente para a idealização do modelo cis-heteronormativo. Cria-se imagens, a exemplo, forma de relacionamento ou de diferenças de roupas entre gêneros, sendo somente uma parte da população capaz de alcançar e normalizando esses padrōes. Trata-se de uma indústria que atrofia a imaginação e espontaneidade, a cultura é retratada de forma homogeinizadora pelo monopólio da indústria cultural (ADORNO, 1986).

Recentemente, criou-se uma indústria supostamente voltada para LGBTI+, em busca do Pink Money. O termo passou a ser utilizado diante da constatação de que o consumo da comunidade LGBTI+ era responsável pela movimentação de 150 milhões de reais ao ano no Brasil, de acordo com a consultoria InSearch Tendências e Estudos de Mercado e, segundo o 
senso do IBGE de 2010, casais do mesmo gênero possuem duas vezes mais renda que os de gênero diferentes, além de gastarem aproximadamente $30 \%$ mais (CÂMARA LGBT, 2018). Diante disso, empresas passaram a criar produtos e produzirem propagandas que atraíssem esse público.

Surge, então, o termo pinkwashing, uma vez que essas empresas, em sua maioria, mostravam inclusão de maneira oportunista, mas não verdadeiramente inclusiva. A representatividade ainda não foi alcançada, anúncios LGBTI+-friendly são muitas vezes criados por homens heterossexuais, brancos e ricos; papeis LGBTI+ na TV são representados por pessoas cis-gênero e heterossexuais; cria-se produtos com cores de arco-íris, mas a empresa em si não suporta a causa ou emprega funcionários que representem a diversidade de gênero e sexual; e quando a visibilidade é permitida, coloca-se uma parcela específica do movimento para aparecer, normalmente homens gays e brancos.

Quando se imagina o universo gay, tirando a visão homofóbica, o que vem à memória são corpos exuberantes, músicas pop, pessoas estilosas e uma felicidade inabalável. Pelo menos é esse painel que você encontra se jogar no Google a palavra "Gay". O que quase ninguém percebe é que todas as pessoas desse mundo ideal são brancas. O padrão gay é branco. (KER, 2017).

Reflexo disto é a maior dificuldade da parada LGBTI+ de madureira de conseguir financiamento, que possibilita outro tipo de representatividade, do que a de copacabana, em que monetariamente é mais atrativo para empresas. A identidade LGBTI+ veiculada é estigmatizada ou representada meramente em busca do pink money, não havendo uma representatividade de fato. Assim, pessoas LGBTI+ não têm referências na mídia ou ao circular pela cidade, precisam buscar em lugares específicos suas redes para se compreender enquanto parte desse grupo e, além disso, pessoas cisgênero e heterossexuais permanecem com a visão estereotipada e perpetuando seu preconceito. 
Mais um componente do lazer seria a relação com as obrigações. O tempo fora do trabalho não é necessariamente tempo de lazer, pois existem preocupações da vida cotidiana que são expressas como obrigações, impedindo esse tempo livre. A questão de atividade está muito ligada à prática de um lazer massificado, mais homogêneo, ligados a valores culturais, no entanto, não é algo que pode ser previsto taxativamente (REQUIXA, 1977). Para realizar políticas públicas, tendo em vista esse elemento, é imprescindível a consulta à população e um processo participativo.

Para classificar as atividades de lazer, Dumazedier utiliza o interesse cultural predominante nelas, estabelece as categorias de físicos, manuais, intelectuais, artísticos e sociais, Luiz Otávio de Lima Camargo (1992) acrescenta os turísticos. É evidente que as atividades são pluridimensionais, mas o autor buscou analisar diante da propriedade dominante. Atém-se, aqui, aos lazeres sociais, em que o contato com x outrx e a sociabilidade são elementos centrais e, por isso, realizáveis em espaços públicos.

Outras formas de lazer também contribuem para a sociabilidade, mas os lazeres sociais especificamente têm como elemento principal o encontro em si, que pode ser, por exemplo, uma festa, reuniões entre amigues ou agrupamentos. É no exercício dessa modalidade que as pessoas se encontram de forma mais livre, podendo se conectar com mais facilidade, constituindo um potente instrumento de integração social (LOPES, 2017). Nele ocorre a troca de informações, valores e conhecimentos, o desenvolvimento da personalidade por meio do contato com o outro e é desenvolvido o sentimento de pertencimento.

A vivência coletiva do lazer é muito relevante, constitutivo da vida urbana, que deve ser garantida em termos de direito à cidade. As comunidades são fortalecidas pelo lazer, unidas as pessoas podem inventar alternativas de lazer, não podendo acessar equipamentos, diversas do lazer hegemônico. Ele pode ocorrer de diversas formas, mas a disponibilidade 
dos meios e equipamentos necessário estimula sua prática, a facilitando (LOPES, 2017).

Um lugar em que as pessoas não se sintam inseridas na harmonia de uma comunidade urbana leva o lazer a ser adstrito a espaços e tempos determinados. O lazer não mais poderá percorrer o cotidiano, as atividades necessárias para a sobrevivência, ele terá local e tempo específicos (ROLNIK, 2000). O lazer encarnado na cidade é aquele que estreita a relação entre cidadãxs, um lazer com funções pessoais na dimensão pública da cidade, componente primordial para a qualidade de vida.

Percebe-se que cada vez mais dissolve-se a diversidade da dimensão pública pluriclassista e heterogênea, que é submetida à restrição de guetos, espaços privativos, fechados e homogêneos. A cidade deveria conectar usos, funções e pessoas diferentes, em segurança (ROLNIK, 2000), e com esse objetivo deveria seguir a atuação do Estado através de políticas públicas.

A Constituição Federal trata do lazer em 4 momentos distintos, além de entender-se que ele está presente implicitamente em outros momentos. $\mathrm{O}$ artigo $217, \mathrm{IV}, \S 3^{\circ}$ elenca esse direito enquanto parte do desporto, o que é problemático por aparentar subordinação quanto a esse, ao passo em que a atividade esportiva é apenas uma ramificação do lazer. O artigo 227 traz esse direito como parte da proteção à criança e ao adolescente; já o artigo $6^{\circ}$, IV que trata do salário mínimo, demonstra a relevância de se garantir, através desse, o lazer; e no caput do artigo $6^{\circ}$ o Lazer é colocado como Direito Social.

Apesar de ter dado status de direito social, a Constituição Federal de 1988 não se definiu seu conteúdo ou formas de concretização dele, o que dificulta a interpretação para sua plena realização. Ao atribuí-lo como direito social criou-se a obrigação estatal de, não apenas garantir o acesso livre, mas atuar positivamente no sentido de proporcionar condições materiais para seu exercício. Ademais, seu conteúdo pode ser extraído por 
uma interpretação sistemática da Carta, através de princípios e valores, da ideia de direitos sociais expressa na própria Constituição e das características dos estudos do lazer.

Segundo Paulo Bonavides (2013), a Constituição de 1988, conhecida como "Constituição cidadã", é a do Estado Social, se contrapondo à do Estado Liberal, e tornando a teoria dos direitos sociais fundamentais e o princípio da igualdade temas essenciais a ela. A igualdade material é um princípio basilar em um sistema constitucional de Estado Social, através do qual deve ser interpretado todos os demais direitos sociais. Assim, indivíduos que ocupam posições assimétricas nas relações de poder da sociedade devem ser tratadas de forma desigual para que ocorra o equilíbrio.

Essa igualdade material prescinde de prestações positivas do Estado, um papel ativo, de promover oportunidades que priorizem grupos menos privilegiados, proporcionando uma existência digna a todxs, conforme os ditames da justiça social. Dessa forma, a isonomia deve estar expressa enquanto garantia do direito ao lazer. A previsão constitucional do direito à cidade deriva especificamente dos artigos $3^{\circ}, 6^{\circ}, 182$ e 225 , que consagram elementos e direitos difusos e sociais com os quais ele se relaciona, como o direito ao lazer e à cultura, aqui identificado no lazer social.

A democratização do lazer é torná-lo acessível a todxs, distribuindo de forma equitativa as possibilidades de sua vivência. Quando o ambiente urbano se torna inóspito para pessoas LGBTI+, é difícil que haja uma postura descuidada, leve e tranquila em espaços públicos, logo, a sociabilidade, em seus diversos aspectos já destacados, resta prejudicada, ocasionando a desigualdade de acesso a esse direito.

Isto é particularmente preocupante com relação a pessoas LGBTI+, pois dependente da criação de redes de afeto e de encontrar locais de pertencimento, está descobrir-se enquanto LGBTI+, sua auto-aceitação e a saída do armário. 
A vida constitui-se pela convivência com pessoas diferentes e a participação de um contrato social de caráter público, que deve basear-se na não-violência e não-força:

A essência do público - seja espaço, convívio ou identidade - que é feita de diferentes linguagens e falas, de troca de olhares, de bens e de amores, acabou minguando, senão regredindo para uma espécie de administração da sobrevivência imediata transformando-se em pura burocracia (ROLNIK, 2000, p. 4).

A dimensão coletiva e multifuncional do espaço público é esvaziado (ROLNIK, 2000). Apenas alguns grupos podem fruir do espaço público com a tranquilidade que demanda para obter lazer nele.

O pavor da maioria dos espaços públicos se caracteriza como um lugar não mais protetor, de conexão e integração, mas de exercício da violência, pois não permite que a diversidade se expresse, rompendo com uma dimensão pública pluriclassista e heterogênea (ROLNIK,2000). O espaço público torna-se de "consenso" da hegemonia, com a existência de lugares de refúgio apartados para quem não se adequa a esse espaço.

O lazer encarnado na cidade, segundo Rolnik (2000), identificado na sua dimensão pública, seria um instrumento importante anti-exclusão. Para ela, organizar, defender e fomentar a convivência entre pessoas diferentes diminui a segregação e a distância social, ampliando a coletividade e facilitando a comunicação. Ocorre que, isto somente é possível diante de políticas públicas que encarem a temática da cis-heteronormatividade imbricada na cidade, o que não é possível se o mito da neutralidade se mantiver. A necessidade de consenso e homogeneidade segrega e, quando se tem uma cidade-armário, busca-se lugares onde é possível expressar sua diversidade de gênero e sexual de forma livre, transitando por esses outros espaços apenas quando estritamente necessário.

A vivência do lazer demanda equipamentos, que seriam os meios que o proporcionam ou auxiliam, sejam eles produtos ou espaços. $\mathrm{O}$ 
ambiente tem relação e influência na qualidade ou inclusive possibilidade de ocorrência da prática do lazer, em muitos casos (LOPES, 2017). Um dos mais importantes elementos pode ser o lugar, principalmente em se tratando de lazer social.

Equipamentos públicos de lazer estão enquadrados em bens públicos de uso comum ${ }^{13}$, como a rua, praças, quadras, parques, áreas de preservação ambiental, praias, museus, cinemas populares, dentre outros. São aqueles que fazem parte da cidade, da política urbana, e devem ser disponíveis para que todos possam frequentar indistintamente. Ocorre que, embora público, há barreiras de outras ordens para a ocupação desses espaços de lazer.

Isto porque esse lazer é gratuito ou a preços baixos, realizado fora de casa, normalmente no coletivo, com a exposição ao contato com variadas pessoas, supostamente promovendo a sociabilidade e o intercâmbio entre pessoas de diferentes realidades, classes sociais e experiências. Nesse convívio deveria ser possível existir a discussão, troca de valores, aprendizado, compartilhamento de comportamentos, modos de falar e se vestir, o que contribui para o desenvolvimento da personalidade do indivíduo, que se enriquece ao entrar em contato com outras pessoas (LOPES, 2017).

Isto é particularmente importante para pessoas LGBTI+ na fase em que estão começando a se entender como tal, como na mídia não há modelos nos quais se possa espelhar nesse sentido e a sociedade em maioria condena pessoas que performam ou demonstram afeto nesse sentido, também como forma de associativismo para incidir politicamente ou resistir a pressões do dia a dia. A cidade sendo um lugar onde essa diversidade encontra-se atrofiada, a mera presença de alguns grupos se torna transgressora, não sendo possível expressar-se, o movimento busca lugares

13 Na definição de Celso Antônio Bandeira de Mello, os bens de uso comum “(...) servem para serem utilizados indistintamente por quaisquer sujeitos, em concorrência igualitária e harmoniosa com os demais, de acordo com o destino do bem e condições que não lhe causem uma sobrecarga invulgar. Esse é o seu uso comum". BANDEIRA DE MELLO, 2012. p.942. 
específicos em que essas redes de sociabilidade e de afeto possam ser criadas.

\subsection{Subculturas e ocupação LGBTI+}

O programa político deve promover as diversidades étnicas, sociais e culturais, não ignorar a relevância da diferença para melhor assimilá-las em uma identidade comum abstrata que converte em cidadãos de segunda classe aqueles que não se enquadrem (DOMINGUES, 2013). Esses sujeitos devem ter a possibilidade de um diálogo de reconhecimento mútuo da diferença, sem que seja estigmatizadxs por formas dominantes, não ocorrendo esse diálogo horizontal (SANTOS, 2003).

Utiliza-se, a fim de identificar essa possibilidade de lazer em determinados espaços, o conceito de cultura, por abrangê-lo. Quando criase espaços de lazer diversos da hegemonia, relaciona-se de outra forma, que pode ser entendida enquanto uma subcultura. Assim, Domingues (2013) as conceitua como "construções dos modos de vida e ações dos sujeitos na e sobre a realidade e, as formas de produção e expressão daquilo que é reconhecido como cultural"'.

Desta problemática, creio ser possível percorrer o que considero ser a primeira atrofia potencial da diversidade. A normatividade construída no universo das políticas culturais precisa privilegiar a dimensão ético-identitária e o que esta representa, as diversas cosmologias e práticas de inserção na vida política e na vida cultural. Se a opção for não fazê-lo, a dimensão cartográfico-institucional pode aparecer como a totalidade das políticas culturais, impondo um certo grau de invisibilidade aos grupos sociais que são, por evidência, os que representam as múltiplas formas de convivência e a possibilidade de renovação do regime democrático. A primeira atrofia significa, portanto, a negação normativa ou o não reconhecimento das múltiplas existências cosmológicas e a construção de formas de gestão que não beneficiem o tratamento das diferenças culturais entre os agentes sociais como elementos estruturantes do resultado político da cultura. (DOMINGUES, 2013, p. 28)

Nenhum Estado pode ser "culturalmente neutro", pois ao reconhecer direitos da cidadania, as instituições liberais introduzem um espectro 
implícito de valores culturais hegemônicos na esfera pública, criando uma "identidade homogênea", o que tem efeito nos direitos individuais (REQUEJO, 1999). Alguns grupos têm mais dificuldade em se adequar às regras quando "em nome da igualdade e não-discriminação, diferenças de identidade são discriminadas e excluídas” (REQUEJO, 1999, p. 98).

É difícil conceber que a efetivação da dignidade da pessoa humana pode ser realizada sem se considerar o espaço público, onde passam grande parte de suas vidas. A rua, sendo um espaço de troca e cruzamentos, constitui um risco grande quando a sociedade considera demonstrações de afeto ou algumas formas de se performar, como uma afronta. É necessário questionar tais espaços como locais de sociabilidade.

A democratização do espaço público demanda a expansão da tolerância e a aceitação de maior indistinção, desmontando sistemas de regulação que mantém hierarquias sociais já introjetadas em práticas cotidianas. Isto não ocorre espontaneamente e, enquanto o Estado não se posiciona com políticas públicas específicas, torna-se dependente de atos transgressivos que forcem os limites do cotidiano da cidade (CALDEIRA, 2014).

A revolução sexual é vista retrospectivamente como um momento em que se eliminou atitudes conservadoras relacionadas ao sexo e reduziu as restrições culturais a esse respeito, no entanto, isso ocorreu principalmente com relação à liberdade sexual de homens heterossexuais (PARKER, 1999). A teoria feminista, posteriormente, questionou alguns pressupostos a respeito das mulheres e, o movimento de direitos de diversidade de gênero e sexual ganhou força a partir de uma crescente subcultura urbana, que coloca em questão a categoria de masculinidade, feminilidade, sexualidade normativa e a noção de corpo (PARKER, 1999).

O movimento trouxe consigo o questionamento a pressupostos cisheterossexistas da lei, ciência, psicologia e teorias de parentesco, alternativas de perceber e incorporar a sexualidade e a coesão e desejo 
políticos necessários para alterar as normas e valores ocidentais sobre sexualidade. Posteriormente, outras militâncias contribuíram para essa luta, como o movimento negro de reivindicação de direitos civis, que aumentam essa consciência, dando nova dimensão à pesquisa sobre sexualidade e denunciando a ligação irrefutável entre sexualidade e poder (PARKER, 1999).

Não se pode compreender o surgimento de subculturas como simples produto de contextos sociais e culturais distintos, apesar de suas particularidades evidentes. É importante perceber que elas atravessam também processos globais de mudança que têm uma similaridade em sua constituição (PARKER, 1999). Não se trata aqui de compreender as relações sociais específicas que gerou cada uma delas, mas situar no interior de processos mais amplos históricos e políticos, a partir de tensões sociais. O sistema de representações sobre a sexualidade é produzido em um contexto político muito mais amplo (FRY, 1981).

É possível perceber espaços onde grupos de pessoas LGBTI+ se reúnem para formar uma resistência à opressão, ser acolhimento axs outrxs e criar apoio e redes. Um local em que se pode estar despreocupadx, trocar com indivíduos que tiveram vivências semelhantes, um espaço livre. Nesses locais, forma-se, normalmente, essa subcultura, incluindo significados, códigos, linguagem, normas, valores, costumes, pontos de encontro, atividades, instituições e tradições.

Nessas redes é possível produzir conhecimento, denunciar o cenário violador e incidir na criação e efetivação de políticas voltadas para necessidades específicas dessa população. Redes de afeto podem significar as criadas com os lugares que se frequenta, são associações que surgem com o movimento entre atores envolvidxs, pelo compartilhamento de saberes. Funcionam como articuladoras entre o público e outros nichos da cidade, possibilitando que a pessoa possa estar confortável nesse ambiente e possa se autoconhecer diante dessa realidade. 
Cabe ressaltar novamente que o Brasil abarca contextos sociais muito diversos e que influenciam diretamente no grau de precariedade da vivência LGBTI+, varia de acordo com região, classe social, momento histórico, também de acordo com a passabilidade ${ }^{14}$ do sujeito, com sua raça etc. Uma pessoa chamada de "bicha" em Belém tem pouco em comum com alguém lido como gay em outras áreas de classe média de metrópoles brasileiras (FRY, 1981).

Dentro do Rio de Janeiro já se pode observar uma grande distinção de acordo com a zona em que está ou se está em favelas ou no asfalto, por exemplo:

\begin{abstract}
Assumir publicamente a sua homossexualidade ou bissexualidade é um ato político bastante corajoso e (infelizmente necessário) (...) Quanto mais raras essas cenas, maior a repressão. Não há dúvida de que a vivência LGBT+ não é a mesma numa praia da Zona Sul e numa comunidade onde namorar alguém do mesmo sexo costuma ser algo escondido, e muitas vezes, considerado "anormal" ou "errado". É urgente naturalizar o amor homossexual e a liberdade de gênero em todas as partes da sociedade, mas o processo é demorado. Quem está se expondo hoje vai abrindo o caminho para as próximas gerações e mudando a cabeça de quem convive diariamente. (...) Outro fator que pode tornar o ambiente da favela mais constrangedor (e mais desafiador) é a proximidade entre as pessoas. Quem é "cria" é conhecido de todo mundo. Não tem como namorar publicamente sem expor a sua identidade e até sua família, o que torna mais delicado ainda o diálogo e a aceitação dentro dela. Nesse sentido, o papel dos movimentos LGBT+ tem sido fundamental nos últimos anos, não só para levantar essas questões em praça pública, mas também para gerar uma consciência coletiva que acaba fortalecendo os indivíduos no seu combate à moral heteronormativa (A VOZ DA FAVELA, 2018)
\end{abstract}

Um espaço de refúgio em que se formou uma subcultura LGBTI+ é a Farme de Amoedo, rua em Ipanema, Zona Sul do Rio de Janeiro, com diversos bares conhecidos por serem amigáveis ao público LGBTI+, assim como a praia em frente a ela, parte de roteiros turísticos LGBTI+ e com visibilidade internacional. Embora seja um local de acolhimento, ainda representa um nicho de aceitação de uma sociedade que tolera apenas

\footnotetext{
14 Passabilidade é a leitura social que uma pessoa tem, por exemplo, uma pessoa trans teria passabilidade de cisgênere se ao circular pela cidade, fosse identificada pela maioria como cis, o que pode ser aplicado para outras letras da sigla LGBTI+. Muitas pessoas buscam passabilidade por questão de segurança em ambientes públicos.
} 
aqueles que podem pagar e atendem a certos padrões corporais e de comportamento.

Frequentam esse espaço exatamente aquelxs que conseguem protagonizar capas de revistas e filmes mais famosos de temática LGBTI+: homens brancos "sarados" (KER, 2018). Corpos exuberantes, música pop, pessoas estilosas e uma felicidade inabalável são elementos do imaginário do universo gay, possível de ser encontrado em pesquisas na internet e parte do cotidiano da Farme de Amoedo (KER, 2018).

Esse padrão é cisgênero e branco e, embora represente uma conquista, a existência desses corpos transitando livremente nesse espaço, ainda configura um ambiente hostil pra as demais letras da sigla LGBTI+e mesmo para os gays que não sejam brancos ou inadequados ao padrão de beleza. O local é, portanto, majoritariamente frequentada pela letra " $G$ " da sigla e, mesmo assim, dentro do padrão branco, cis, "sarado" e rico. O homem gay negro afeminado, não sendo sexualizado e objetificado, poderá enfrentar dificuldades em se enquadrar no local.

Cabe ressaltar, ainda, que esses locais de refúgio, mesmo para quem se sente segurx nele, podem configurar um local de difícil acesso, pois a trajetória de ida e volta do local apresentam perigos. Ademais, esses locais geram desconforto em muitxs privilegiadxs, que os veem como espaços "heterofóbicos", conceito que não existe em termos práticos, uma vez que a fobia, nesse sentido, deriva de uma relação de poder e, na cultura que vivemos, heterossexuais não estão em posição de opressão. Esses locais de refúgio não são proibidos a pessoas cisgênero e heterossexuais, apenas é rejeitada a $\mathrm{LGBTI+fobia.}$

Em Madureira, Zona Norte do Rio de Janeiro, foi consolidado um ambiente de acolhimento principalmente para pessoas gays, travestis e transformistas. O encontro antes se dava no shopping de Madureira, facilitado com o uso da internet, um andar específico do estabelecimento ficou conhecido como "andar gay". Eram confraternizações em um espaço 
que lhes dava segurança. Segundo Loren Alexander, presidente do MGTT (movimento de Gays, Travestis e Transformistas) ${ }^{15}$, "é a importância da multidão para dar liberdade de expressão", e os encontros serviam para discussões de cidadania, que levou à criação da parada LGBTI+ de Madureira, assim como muitas ações de cidadania voltadas para esse público nasceram em rolezinhos ${ }^{16}$ como esses (CALDEIRA, 2014). Fernando Pereira, frequentador do rolezinho gay, afirma a liberdade de "ser quem é" no shopping:

Quando eu comecei a frequentar os encontros no Madureira eu ainda estava começando a assumir minha sexualidade até para mim mesmo. $\mathrm{O}$ fato de ter ido a um lugar que eu encontrava pessoas que tinham a mesma cabeça que a minha foi libertador. Foi um período muito rico da minha juventude. Fiz amizades que duram até hoje. Era uma diversidade muito grande. vez ou outra acontecia alguma confusão. Cara, eram 800 pessoas espremidas num único andar. Aquilo era como a praia de um gay suburbano. Quem nunca testemunhou uma confusão entre heterossexuais numa praia? Qualquer lugar onde junta muita gente pode acontecer isso. Eu acho que a grande culpa é da sociedade que por não nos aceitar nos impõe um comportamento de manada, a ficar em grupo para se sentir seguro (CALDEIRA, 2014).

Segundo Loren, um dos principais problemas que surgiram foram comportamentos LGBTI+fóbicos por parte de comerciantes e, após chamarem inúmeras vezes policiais e perceberem que a denúncia não tinha resultado, e com o aumento dessa repressão, acrescida do fato de que o shopping era uma estrutura pequena para o movimento que se formara, optou-se por mudar a localização para uma rua escura e com pouco movimento de pedestres, a antiga travessa Almerinda Freitas. Em 2014, a rua foi renomeada para "Rua da Diversidade" em cerimônia dos 20 anos de luta por direitos sociais, um espaço de acolhimento (CALDEIRA, 2014).

\footnotetext{
15 transformista é o termo que abarca drag queens e drag kings, artistas que se "montam", ou seja, se vestem com roupas usualmente "próprias" do gênero oposto em performances ou em baladas, para fins artísticos ou de entretenimento. Sua personagem não tem relação com identidade de gênero ou orientação sexual.

16os "rolezinhos" surgiram convocados por cantores de funk em 2017, em resposta a um projeto de lei que proibia bailes nas ruas da capital de São Paulo. Jovens da periferia, majoritariamente negres, passaram a frequentar shoppings em zonas privilegiadas, o que repercutiu em muitas reclamações, respaldadas posteriormente por uma decisão judicial que permitia a triagem de clientes, e ocasionando ainda mais repressão policial aos participantes. Muitos eventos de encontro LGBTI+ chamam-se de "rolezinhos" por trazerem conceito semelhante em sua atuação.
} 
A Casa Nem, criada pela Indianare Siqueira, mulher travestigênere ${ }^{17}$, militante de direitos LGBTI+, é um símbolo de luta, resistência e poder. Lá transexuais, travestis e transgêneros encontram acolhimento e apoio, um lugar onde podem dormir, onde são feitas oficinas, debates, festas e shows, empoderando o público LGBTI+ em situação de vulnerabilidade social. Ela se localiza na Lapa, com festas que financiam a casa, sem que pessoas trans paguem por nenhuma atividade.

É parte da casa o PreparaNem, fundado em 2015, que é um cursinho preparatório para o ENEM e que, em 2016, passa a ser realizado também em Niterói e na Maré. Também são oferecidas aulas de costura, fotografia, história da arte, libras e yoga, tudo voltado para o público trans e "quem se considere Nem", segundo Indianare. A moradia é constituída como "casa de passagem", acolhimento até que a pessoa consiga reestruturar sua vida e ceder espaço para outrxs.

Nos locais onde não estão estabelecidas essa dinâmica social que possibilita o conforto, a cidade permanece sendo um espaço de luta, então o movimento de militância LGBTI+ encontrou diversas formas de realizar críticas sociais e expor as precariedades do atual sistema. Além da resistência pela rede de afeto e espaços de refúgio que são criadas pelos ambientes conquistados em que há uma ocupação de vivências, subculturas, há outras formas de organização de militância que foram construídas em busca de incomodar a cena urbana para expor esse contexto que permeia a vida dessas pessoas, naturalizar suas existências e empoderar outrxs a se assumirem nesse contexto.

Exemplo disso é a Gaymada. Em diversos lugares do Brasil, grupos de LGBTI+ se organizam para jogar regularmente ou esporadicamente um jogo de queimada, em que além da reunião com troca de afetos, uma forma de lazer em público e lugares inóspitos, torna-se um momento de liberdade

\footnotetext{
17 Indianare se denomina assim, nomenclatura mais inclusiva para pessoas trans, abarcando travesti e transgênero, com a utilização do "e" para não distinguir um gênero específico, podendo se tratar de não-binárie. Diz que é "mulher de peito e pau".
} 
nesses locais, dá para jogar, ouvir música, beber e “dar pinta”. Resistir em grupo dá mais força. (FONTE)

Evidentemente ainda há muitos desafios, muitos grupos ainda são agredidos nesses momentos, surpreendidos enquanto estão indo pra casa. É uma forma de resistência, mobilização e união leve, que busca quebrar preconceitos. Pessoas LGBTI+ são associados à noite, baladas, demonstra o estereótipo baseado em quem precisa se esconder. Em eventos como esse, muitas vezes incluem campanhas para angariar doações ou parcerias para distribuição de preservativos e realização de exames de HIV.

Outra estratégia nesse sentido é o Beijaço, que consiste em uma forma de protesto em que casais do mesmo sexo se beijarem dentro ou diante de algum lugar que tenha reprimido uma manifestação de afeto prévia ou ou ocorrido alguma violência física ou simbólica quanto a isso. O termo foi criado em 2003 em uma manifestação no Shopping Frei Caneca em São Paulo, diante de um caso em que um casal de pessoas do mesmo gênero haviam sido expulsos por se beijar na praça de alimentação. $O$ ato ocorreu com 2 mil pessoas e muitos Beijaços ocorreram a partir de então (G1, 2013). Segundo um dxs organizadorxs do ato, Thiago Bassi:

Nós não queremos estar em guetos e não aceitaremos mais ser expulsos de lugar nenhum. Temos direito a frequentar todos os espaços e a exercermos a nossa cidadania livremente (SILVEIRA, 2015).

Da necessidade e desejo de ocupar o espaço público o resignificando para que fosse construído um espaço seguro e de fortalecimento da sociabilidade e cultura LGBTI+, surgem eventos como o Isoporzinho das Sapatão e Velcro criados por e para mulheres lésbicas e bissexuais, cis e trans, que são colaborativos e itinerantes. São coletivos que objetivam ampliar as possibilidades de experienciar a cidade, estimulando o empoderamento a partir da afirmação de identidades e se colocando contra a LGBTI+fobia e outros tipos de opressão. 
Neles, não há restrição de ninguém, independente de orientação sexual ou identidade de gênero, bastando apenas a vontade de apoiá-los. Segundo organizadoras do evento, o grupo surgiu de um evento público do Facebook em 2015 que obteve um número de pessoas maior do que o esperado e, com a grande adesão, mostrou a real necessidade desse espaço. A proposta é ser itinerante para que a diversificação do local permita a contemplação do maior número de lésbicas e bissexuais possível. (ISOPORZINHO DAS SAPATÃO, 2018).

Surgiu, em 2018, o Isopormício, da ideia de que a experiência da vida política por bissexuais e lésbicas se dá de forma própria e de que o poder político e a importância de se unir é cada vez mais relevante diante de uma sociedade misógina e de violações constantes de seus afetos e liberdade. Logo, pensar a cidade, cultura, saúde, segurança pública, educação e a inclusão através desse olhar é fundamental para construir uma cidade mais justa e diversa.

A proposta desse evento veio de Tainá de Paula, mulher negra, bissexual, favelada, feminista, arquiteta e urbanista, que pauta as formas de se divertir para além de existir na cidade. A proposta era de, em um ano eleitoral, conhecer companheiras de luta e representantes potentes para a viabilidade e o avanço político de suas pautas, debatendo e construindo com elas. Junta-se festa, militância, política e comício em um só espaço, com o acolhimento de pessoas que na maioria dos espaços se sentem reprimidas, não podendo expressar-se com tranquilidade, se posicionar ou ser quem são (MOREIRA, 2015).

Assim como esses, há muitos espaços e eventos de acolhimento para pessoas LGBTI+ criados pela militância. O afeto, contato e acolhimento é muito importante, pois essa violência e preconceito constante deixa pessoas LGBTI+ mais vulnerável ao suicídio. Partilhar e interpretar sua experiência no convívio com outras pessoas LGBTI+ pode contribuir para uma identidade mais concreta e positiva de si. A Universidade de Columbia dos EUA realizou estudos sobre o assunto com 32 mil participantes entre 13 e 
17 anos e concluiu que adolescentes LGB são 5 vezes mais propensos a tentar suicídio do que pessoas heterossexuais (TODXS, 2018). O Brasil ainda não realizou nenhuma pesquisa semelhante, no entanto, o Grupo Gay da Bahia apontou 58 casos em 2017. A profundidade do problema ainda não foi possível de ser identificada por falta de dados oficiais, questão apontada pela OEA em 2004.

Embora muito relevante para a vivência LGBTI+ nas cidades, essas formas de ocupação de espaços públicos são somente necessárias diante da inércia do Estado em provê-las. A garantia do direito ao lazer e, de forma mais ampla, o direito à cidade depende de uma prestação positiva estatal da qual ele se exime.

\subsection{Direitos sociais e a demanda de atuação positiva}

A Constituição de 1988 representou um grande avanço, mas não conseguiu promover uma ruptura com as estruturas hierárquicas e autoritárias de poder. O avanço do neoliberalismo a partir da década de 1990 ameaçou conquistas importantes (LOPES, 2017). A transição neoliberal no Brasil iniciou-se com a eleição de Fernando Collor como presidente em 1989, com seu apogeu no governo de Fernando Henrique Cardoso, em 1994 a 2002, que ainda permanece. Esse projeto pretende um Estado mínimo que diminui progressivamente a responsabilidade social, transferida à sociedade civil. Com o Estado se eximindo do papel de garantidor de direitos, os direitos sociais, principalmente, restam enfraquecidos (LOPES, 2017). Busca-se aqui refletir sobre o acesso a esse direito e de que forma sua concretização vem sendo negligenciada.

Operam, na doutrina e na jurisprudência, teorias como a do mínimo existencial que, segundo Ricardo Lobo Torres (2008, p. 324-326), representa um limite às restrições dos direitos sociais, que devem garantir uma parcela indisponível aquém da qual a possibilidade de viver com 
dignidade não existiria, sendo o excedente a isso passível de restrição pelo legislador; e a da reserva do possível que, segundo o mesmo autor, é um conceito que condiciona a exigência de direitos sociais à disponibilidade financeira do erário público, compreendendo recursos disponíveis no Tesouro ou dotação orçamentária para o fim específico.

Quando se aplicam essas teorias, permite-se que sejam estabelecidas gradações de respeito entre brasileiros. Os direitos sociais são um compromisso formalmente adotado pelo Estado através do constituinte originário que influencia diretamente na formação de identidade (PIRES, 2013). Essa obrigação confere legitimidade à ordem democrática e são condições para o exercício da cidadania plena, não uma opção política (LOPES, 2017). A distinção feita pela doutrina entre direitos civis e políticos e os sociais, usualmente, é de que os primeiros são prestações negativas, enquanto os últimos são positivas, logo, muitxs entendem que estariam dependentes da disponibilidade do erário público, sendo inviável a sua realização em muitas ocasiões, constituindo direitos apenas no sentido figurado (LOPES, 2017).

$\mathrm{O}$ argumento financeiro e o de limitação do mínimo existencial enfraquecem os direitos sociais, que deixam de ser efetivados à medida que não são considerados uma obrigação do Estado. O primeiro é, ademais, pautado em uma falácia, uma vez que direitos individuais também geram custos, ainda que em menor grau, da mesma forma que direitos sociais também geram obrigações de fazer, por exemplo, no que tange o lazer, o Estado deve assegurar a não interferência no mesmo, protegê-lo de eventuais violações e não o violar ele mesmo. No entanto, há uma inegável necessidade de prestação positiva (LOPES, 2017).

Abramovich e Courtis (2002) explicam os graus de prestação estatal com relação à concretização de direitos a partir de 3 categorias, a de respeitar, proteger e satisfazer, elementos também adotados pelo Comite de Direitos Econômicos, Sociais e Culturais da ONU. Respeitar seria a não interferência de acesso ao objeto do direito; proteger seria impedir que 
terceiros interfiram em sua concretização; e satisfazer seria prover as condições para que os titulares do direito acessem o bem. Todas essas obrigações podem ser aplicadas no que tange o direito ao lazer e, mais amplamente, o direito à cidade como um todo.

O lazer democrático, acessível a todxs, que corrige desigualdades, depende de uma cidade cuja apropriação por seus cidadãos seja possível. Enquanto ela apresentar a circulação enquanto privilégio, o lazer em espaços públicos permanecerá restrito a uma parcela da população. São direitos sociais, cujo conteúdo estabelece moldes e valores a serem observados pelo legislador, o administrador público na formulação de políticas públicas específicas e não específicas e do aplicador do direito. Ele perpassa todo o Poder Público.

Não será abordado neste trabalho as possibilidades de justiciabilidade desse direito social, embora seja entendido como uma necessidade a gestão democrática da cidade, concretizando instrumentos que a viabilizem. Deve ser implementado, ademais, formas factíveis de exigência do cumprimento de normas de direitos sociais e instrumentos processuais concretos para solucionar a violação de obrigações relativas aos direitos sociais, especificamente com relação à parcela da população que já não consegue acessá-lo. 


\section{CONCLUSÃO}

O direito à cidade é um direito fundamental, de natureza difusa, composto por outros direitos sociais e difusos, regido pela solidariedade e que permite a realização do princípio da dignidade da pessoa humana. Entende-se que sua natureza não é programática, logo constitui obrigação do Estado a adoção de políticas públicas para sua efetivação.

É difícil elaborar o conteúdo desse direito pois trata-se de uma interrelação entre os direitos que o constitui, além de depender das demandas dxs cidadãxs, uma vez que deve ser moldado pela perspectiva política integrando o poder de decidir, suas formas de viver o espaço urbano, definir seus destinos e de se apropriar do mesmo, modificando-o.

Há uma carga alta de politização a partir da concretização do direito à cidade, deve-se cuidar para que não seja utilizado como um conceito vazio e legitimador de uma cidade ainda mais excludente, com impossível aplicação judicial. (GUIMARÃES 2017).

Trata-se de um direito coletivo e valor social-político e filosófico, que ocupa uma centralidade no ordenamento jurídico brasileiro. A urbanização depende da associação desses direitos que compõem o direito à cidade e que são indivisíveis, como o lazer, mais profundamente tratado neste trabalho, que produzem o conteúdo da cidade e em conjunto garantem cidades justas, inclusivas, resilientes e democráticas. Valor indispensável a seu cumprimento, efetivando seu poder de transformação, é a gestão democrática das cidades, pautando-se o conflito e a diversidade, intrínsecos ao contexto urbano (GUIMARÃES 2017).

$\mathrm{O}$ direito à cidade deve permitir o questionamento de projetos que privilegiam o falso consenso em torno de ideias abstratas de cidade. No entanto, o que se vê é uma homogeneidade na maioria dos espaços da cidade, mantendo e aprofundando desigualdades em seu acesso, por meio 
da disponibilização diferenciada de espaços públicos, equipamentos e serviços públicos imperiosos a sua realização.

O diálogo ocorre com uma disparidade de forças muito grande, perpetuando a existência apenas de valores dominantes, como a cisheteronormatividade. A cidade torna-se um lugar de mitigação de subjetividades, pela rejeição de sexualidades e identidades de gênero desviantes da "normalidade" imposta (CARVALHO; MACEDO JÚNIOR, 2017).

Como resultado desses discursos pró-família, moralizantes e biologizantes, perdura-se a cidade-armário, a noção de que o ambiente de ocultação da diversidade de gênero e sexual é expandido para o âmbito urbano. Isto leva ao apagamento e também de violência perante pessoas LGBTI+, que se sentem deslocadas na maioria dos espaços.

Essa estrutura revela a opressão de uma cultura cis-heterossexista, se a cidade se produz enquanto reflexo de interesses e pensamentos dominantes na sociedade, essas consequências derivam de uma normatização presente em diversos âmbitos da mesma.

Essa reflexão demanda repensar a distribuição de corpos no espaço urbano, como esses discursos produzem a marginalização e violência urbana contra esse grupo específico, como os corpos dissidentes transitam, habitam e acessam sua cidade. A sacralização de um "lugar de respeito" é um não-lugar para muitxs LGBTI+, criada a cidade interdita, e seus mecanismos de controle são aparentemente sutis, por micro-poderes que xs apaga e xs segrega (CARVALHO; MACEDO JÚNIOR, 2017).

A diversidade atrofiada no espaço público prejudica o acesso a equipamentos de lazer que garantem o lazer social. A cidade sendo um dos espaços de fruição do lazer, os problemas da cidade interferem e obstaculizam o lazer, devendo ser observados. As condições materiais para sua efetivação demandam a possibilidade de estar confortável em ambientes 
públicos, sem o constante medo, a possibilidade de encontros, convivência com pessoas diferentes e de trocas na cidade.

A coletividade ampliada incentiva e aumenta a comunicação entre os projetos de vida e de sociedade intrínsecos ao direito à cidade. O lazer, diante da Constituição Federal de 1988, é um direito social e deve ser priorizado como elemento da dignidade da pessoa humana, devendo ser uma prioridade enquanto obrigação estatal, impassível de justificação por teorias que inferiorize sua concretização enquanto decisão política.

A efetivação de direitos sociais demanda, outrossim, uma prestação positiva do Estado. O movimento LGBTI+ criou diversos mecanismos de resistir às opressões, como formas de ocupação de espaços públicos hostis a elxs, e espaços de acolhimento e refúgio para que se unam, aumente sua força política e formem redes de afeto, muitas vezes impossíveis de serem garantidas em casa.

Não obstante seja celebrada essa união, representa um sintoma de uma cidade que não aceita pessoas LGBTI+, apenas es tolera em casos específicos. Local de lazer e possibilidade de circular deveriam ser todos os lugares, o trabalho, o caminho para ele, perto de casa, em sua vizinhança ou longe dela, a praia inteira, também o shopping de Madureira, e não só uma parte da lapa.

A militância conquistou diversos avanços, mas não consegue garantir que pessoas trans não destransicionem, ou seja, voltem a performar conforme o gênero que foi designado ao nascer, que pessoas LGB+ voltem ao armário, ou que a violência perante esse grupo permaneça extremamente elevada.

Faz-se primordial o fortalecimento da concepção de direitos humanos que abarque direitos de cidadania. A reapropriação de espaços urbanos depende de um rompimento do modelo urbano limitador de acesso à cidade e a democratização de sua gestão. Isto somente será possível se a 
cis-heteronormatividade for constatada e tratada enquanto desafio para o planejamento de uma cidade democrática em seus diversos componentes.

É relevante ressaltar que, ainda que solucionado esse viés, para consolidar os valores desse direito, deve-se ainda atentar para os demais grupos oprimidos e apagados pelo discurso hegemônico e padrão de cidadania, passando a ser consideradas suas reivindicações específicas. São elas as estigmatizações de ordem social, territorial, racial, dentre outras, que formam barreiras entre pessoas dignas e indignas de fruir da cidade. Diversas interseccionalidades relevantes não foram abordadas devido ao escopo do trabalho, mas que devem ser estudadas diante da complexidade das relações de poder que atravessam o tema. 


\section{REFERÊNCIAS BIBLIOGRÁFICAS:}

ABRAMOVICH, Victor; COURTIS, Christian. Los derechos sociales como derechos exigibles. $1^{\mathrm{a}}$ ed.. Madrid: Editorial Trotta, 2002. 256 p.

ADORNO, Theodor W.; HORKHEIMER, Max. Dialética do Esclarecimento: fragmentos filosóficos. 2a ed.. Rio de Janeiro: Jorge Zahar, 1986.

ALFONSIN, Betânia de Moraes. Cidade para todos/Cidade para todas: Vendo a cidade através do olhar das Mulheres. In: ALFONSIN, Betânia de Moraes; FERNANDES, Edésio (Org.). Direito Urbanístico: estudos brasileiros e internacionais. Belo Horizonte: Del Rey, 2009. p. 253-264.

ANDRADE, Daniela. Reportagem. Quem tem medo do termo 'cis'?. 2014. Blogueiras Feministas. Disponível em $<$ https://blogueirasfeministas.com/2014/04/30/quem-tem-medo-do-termocis/>. Acesso em 12 nov. 2018.

ANTRA. Reportagem. Pessoas trans relatam dificuldades em realizar a retificação registral nos cartórios. Antra, 2018. Disponível em $<$ https://antrabrasil.org/2018/08/03/pessoas-trans-relatam-dificuldades-emrealizar-a-retificacao-registral-nos-cartorios/> Acesso em 19 nov. 2018. ARAÚJO, Vera. Filho de Witzel diz que se sentiu 'usado' pelo candidato. $\mathrm{O}$ Globo, 2018. Disponível em <https:/oglobo.globo.com/brasil/filho-dewitzel-diz-que-se-sentiu-usado-pelo-candidato-23181424> Acesso em 18 nov. 2018

BAGAGLI, Beatriz Pagliarini. A diferença trans no gênero para além da patologização. Revista Periódicus: Revista do Grupo de Pesquisa CUS Cultura e Sexualidade, do Programa Multidisciplinar de Pós-graduação em Cultura e Sociedade da UFBA. Salvador, v.1, n.5, p.87-100, maio/outubro, 2016.

BANDEIRA DE MELLO, Celso Antônio. Curso de Direito Administrativo. 29a ed.. São Paulo: Malheiros Editores, 2012. 942 p. 
BENTO, Berenice.Transviad@s: gênero, sexualidade e direitos humanos. $1^{\mathrm{a}}$ ed.. Salvador: EDUFBA, 2017. 329 p.

BERNER, Vanessa Oliveira Batista; MELINO, Heloisa. Perspectivas feministas e movimentos sociais. Revista de Direito da Cidade. Rio de Janeiro, vol. 8, n. 4, p. 1868 1892, 2016.

BONAVIDES, Paulo. Curso de Direito Constitucional. $28^{\mathrm{a}}$ ed.. São Paulo: Malheiros Editores, 2013. 869 p.

BORTONI, Larissa. Reportagem. Expectativa de vida de transexuais é de 35 anos, metade da média nacional. Senado Notícias, 2017. Disponível em $<$ https://www12.senado.leg.br/noticias/especiais/especialcidadania/expectativa-de-vida-de-transexuais-e-de-35-anos-metade-damedia-nacional $>$ Acesso em 5 nov. 2018.

BRASIL, BRASÍLIA. Lei Federal $\mathrm{n}^{\circ}$ 10.527, 10 de julho de 2001. Estatuto da Cidade: Regulamenta os arts. 182 e 183 da Constituição Federal, estabelece diretrizes gerais da política urbana e dá outras providências.

. Conselho Nacional de Justiça. Provimento ${ }^{0} 63$ de 14 nov. 2017. Institui modelos únicos de certidão de nascimento, de casamento e de óbito, a serem adotadas pelos ofícios de registro civil das pessoas naturais, e dispõe sobre o reconhecimento voluntário e a averbação da paternidade e maternidade socioafetiva no Livro "A" e sobre o registro de nascimento e emissão da respectiva certidão dos filhos havidos por reprodução assistida. Disponível em: <http://www.cnj.jus.br/busca-atosadm?documento $=3380>$ Acesso em 19 nov. 2018.

. Conselho Nacional de Justiça. Provimento ${ }^{0} 73$ de

28 de junho de 2018. Dispõe sobre a averbação da alteração do prenome e do gênero nos assentos de nascimento e casamento de pessoa transgênero no Registro Civil das Pessoas Naturais (RCPN). Disponível em $<$ http://www.cnj.jus.br/busca-atos-adm?documento=3503> Acesso em 19 nov. 2018.

. Ministério da Saúde. Portaria no 2.803 de 19 nov. 2013. Redefine e amplia o processo transexualizador no sistema único de 
saúde.

Disponível

em

$<$ http://bvsms.saude.gov.br/bvs/saudelegis/gm/2013/prt2803_19_11_2013.h tml> Acesso em 19 nov. 2018.

. Ministério da Saúde. Portaria no 457 de 19 ago.

2008.

Disponível

em

$<$ http://bvsms.saude.gov.br/bvs/saudelegis/sas/2008/prt0457_19_08_2008.h

tml> Acesso em 19 nov. 2018

BREJEIRAS. Monica Benicio afirma: 'Vai ter beijo e vai ter luta'. Revista Brejeiras. Rio de Janeiro, n. 2, p. 15 16, jun./ago. 2018.

BUTLER, Judith; SPIVAK, Gayatri. Who sings the Nation-State? Language, Politics, Belonging. 2 ${ }^{\mathrm{a}}$ ed.. New York: Seagull. 2011. 121 p.

BUTLER, Judith. Bodies that matter. On the Discursive Limits of "Sex". $3^{\mathrm{a}}$ ed.. New York: Routledge, 2011. 226 p.

. Bodies that matter. On the Discursive Limits of "Sex". $3^{\mathrm{a}}$ ed.. New York: Routledge, 2011. 226 p.

. Corpos que pensam: sobre os limites discursivos do sexo.

In: LOURO, Guacira Lopes (Org.). O corpo educado: pedagogias da sexualidade. Trad. Tomaz Tadeu da Silva. Belo Horizonte: Autêntica, 2003. p. 151-172.

. Excitable Speech: a Politcs of the Performatives. Nova

York: Routledge, 1997.

. O não pensamento em nome do normativo. In: Quadros

de guerra: quando a vida é passível de luto. $1^{\mathrm{a}}$ ed.. Rio de Janeiro: Civilização Brasileira, 2015. 288 p.

- Problemas de gênero: feminismo e subversão da identidade. 15ª ed.. Rio de Janeiro: Civilização Brasileira, 2017.

- Restaging the Universal: Hegemony and the Limits of Formalism. In: BUTLER, Judith; LACLAU, Ernesto; ZIZEK, Slavoj. Contingency, Hegemony, Universality: Contemporary Dialogues on the Left. Nova York: Verso, 2000. 
CAESAR, Gabriela. Reportagem. Quase 300 transgêneros esperam cirurgia na rede pública 10 anos após portaria do SUS. Globo. 2018. Disponível em $<$ https:/g1.globo.com/ciencia-e-saude/noticia/2018/08/19/quase-300transgeneros-esperam-cirurgia-na-rede-publica-10-anos-apos-portaria-dosus.ghtml> Acesso em 20 out. 2018.

CALDEIRA, João Paulo. Reportagem. A história dos rolezinhos LGBT em Madureira, há 15 anos atrás. Jornal GGN, 2014. Disponível em $<$ https://jornalggn.com.br/noticia/a-historia-dos-rolezinhos-lgbt-emmadureira-ha-15-anos-atras $>$ Acesso em 4 out. 2018.

CALDEIRA, Teresa Pires do Rio. Qual a novidade dos rolezinhos?: Espaço público, desigualdade e mudança em São Paulo. Revista Novos Estudos CEBRAP. São Paulo, n. 98, p. 13 20, mar. 2014.

CÂMARA LGBT. Pink Money ou Pinkwashing. 2018. Disponível em $<$ http://www.camaralgbt.com.br/pink-money-ou-pinkwashing/> Acesso em 18 nov. 2018

CAMARGO, Luiz Octavio de Lima. O que é lazer. $3^{\mathrm{a}}$ ed.. São Paulo: Editora Brasiliense, 1992.

CARVALHO, Claudio Oliveira; MACEDO JÚNIOR, Gilson Santiago. Isto é um lugar de respeito!: A construção heteronormativa da cidade-armário através da invisibilidade e violência no cotidiano urbano. Revista de Direito da Cidade. Rio de Janeiro, vol. 9, n. 1. p. 103 116, 2017.

CARVALHO, Nilton; FRANÇA, Isadora Lins. Reportagem. ACNUR lança cartilha informativa sobre a proteção de pessoas LGBTI em situação de refúgio. $2017 . \quad$ Disponível em: $<$ http://caritassprefugio.wixsite.com/casp/singlepost/2018/06/05/Solicitantes-de-ref\%C3\%BAgio-e-refugiados-LGBTItrajet\%C3\%B3rias-e-desafios>. Acesso em: 13 nov. 2018.

CFM. Reportagem. REPRODUÇÃO ASSISTIDA: CFM anuncia novas regras para o uso de técnicas de fertilização e inseminação no País. Portal CFM. $2017 . \quad$ Disponível em 
$<$ https://portal.cfm.org.br/index.php?option=com_content\&view=article\&id =27275:2017-11-09-13-06-20\&catid=3> Acesso em 20 out. 2018.

CIDH, Convenção Interamericana de Direitos Humanos. Observações preliminares da visita in loco da CIDH ao Brasil. 12 de novembro de 2018. Disponível em $<$ http://www.oas.org/es/cidh/prensa/comunicados/2018/238OPport.pdf > Acesso em 15 nov. 2018.

Cieglinski, Amanda. Reportagem. Mais de um terço de alunos LGBT sofreram agressão física na escola, diz pesquisa. Agência Brasil, 2016. Disponível em <http://agenciabrasil.ebc.com.br/educacao/noticia/201611/mais-de-um-terco-de-estudantes-lgbt-ja-foram-agredidos-fisicamentediz> Acesso em 5 nov. 2018.

CRUZ, Cíntia. Reportagem. Transexual é espancada por quatro homens na Baixada Fluminense. Jornal Extra. Disponível em $<$ https:/extra.globo.com/casos-de-policia/transexual-espancada-por-quatrohomens-na-baixada-fluminense-23146402.html>. Acesso em 12/11/2018. CRUZ, Maria Teresa. Reportagem. Travesti é assassinada no centro de SP sob gritos de 'Bolsonaro presidente'. Ponte Jornalismo. Disponível em $<$ https://ponte.org/travesti-e-assassinada-a-facadas-no-centro-de-sp-sobgritos-de-bolsonaro-presidente/?fbclid=IwAR3fN4gOEcNT50xPiDTWOrFU8DMnAiFIHJk0F0bhC01BXEplc3ROqchqhI>. Acesso em 12/11/2018.

CURIEL, Ochy. La Nación Heterosexual: Análisis del discurso jurídico y el régimen heterosexual desde la antropología de la dominación? $1^{\mathrm{a}}$ ed.. São Paulo: En La Frontera, 2013. 197 p.

DOMINGUES, João Luiz Pereira. Diversidade Atrofiada: políticas de regulação urbana e movimentos culturais insurgente na cidade do Rio de Janeiro. Rio de Janeiro. 2013. XXX p. Tese (Doutorado em Políticas Públicas). Instituto de Pesquisa e Planejamento Urbano e Regional da Universidade Federal do Rio de Janeiro. 
DUARTE, Marise Costa de Souza. O direito à cidade e o direito às cidades sustentáveis no Brasil: o direito à produção e fruição do espaço e o enfrentamento do déficit de implementação. Revista Fides: Revista de Filosofia do Direito do Estado e da Sociedade da UFRN. Natal, v. 6, n. 1, p. $1533,2015$.

DUMAZEDIER, Joffre. Lazer e Cultura Popular. São Paulo: Editora Perspectiva, 1976.

DUMAZEDIER, Joffre. Sociologia Empírica do Lazer. $1^{\mathrm{a}}$ ed.. São Paulo: Editora Perspectiva, 1979.

ERIBON, Didier. Reflexões sobre a questão gay. $1^{\mathrm{a}}$ ed.. Rio de Janeiro: Companhia de Freud, 2008. 455 p.

FANON, Frantz. Pele negra, máscaras brancas. $1^{\mathrm{a}}$ ed.. Salvador: EdUfba, 2008. 194 p.

FERNANDES, Edésio. A nova ordem jurídico-urbanística no Brasil. In: ALFONSIN, Betânia de Moraes; FERNANDES, Edésio (Org.). Direito urbanístico: estudos brasileiros e internacionais. Belo Horizonte: Del Rey, 2007. p. 3-23.

FÓRUM MUNDIAL DO DIREITO À CIDADE. Carta Mundial do Direito à Cidade. Disponível em:<http://www.polis.org.br/uploads/709/709.pdf $>$. Acesso em 02 set. 2018.

FOUCAULT, Michel. História da sexualidade 1: a vontade de saber. $13^{\mathrm{a}}$ ed.. Rio de Janeiro: Edições Graal, 1988. Disponível em $<$ https://edisciplinas.usp.br/pluginfile.php/2940534/mod_resource/content/1 /Hist\%C3\%B3ria-da-Sexualidade-1-A-Vontade-de-Saber.pdf $>$. Acesso em 18 nov. 2018.

. História da sexualidade II: o uso dos prazeres. $8^{\mathrm{a}} \mathrm{ed}$.

Rio de Janeiro: Edições Graal, 1984. Disponível em $<$ https://edisciplinas.usp.br/pluginfile.php/2940574/mod_resource/content/1 $/$ Hist $\% C 3 \%$ B3ria-da-Sexualidade-2-O-Uso-dos-Prazeres.pdf $>$. Acesso em 18 nov. 2018. 
. Microfísica do poder. $23^{\mathrm{a}}$ ed.. São Paulo: Edições

Graal, 2004

FRY, Peter. Da hierarquia à igualdade: a construção histórica da homossexualidade no Brasil. In: FRY, P (Org.). Para inglês ver: identidade e política na cultura brasileira. Rio de Janeiro: Zahar, 1981.

G1. Reportagem. Igreja é pichada com símbolo da suástica nazista em Nova Friburgo, no RJ. O Globo. Disponível em <https:/g1.globo.com/rj/regiaoserrana/noticia/2018/10/14/igreja-e-pichada-com-simbolo-da-suasticanazista-em-nova-friburgo-no-rj.ghtml>. Acesso em 12/11/2018.

- Reportagem. Manifestantes fazem ato contra deputado Marco Feliciano em SP. G1, 2013. Disponível em <http://g1.globo.com/saopaulo/noticia/2013/03/manifestantes-fazem-ato-contra-deputado-marcofeliciano-em-sp.html> Acesso em 10 out. 2018.

GLOBO. Reportagem. A realidade LGBT no Brasil preocupa: a cada uma hora alguém é discriminado. Globo, 2018. Disponível em $<$ https://radioglobo.globo.com/media/audio/205455/realidade-lgbt-nobrasil-preocupa-cada-uma-hora-al.htm> Acesso em 19 nov. 2018.

GOFFMAN, Erving. Stigma: Notes on the management of spoiled identity. $1^{\mathrm{a}}$ ed.. Harmondsworth: Penguin, 1968. 173 p.

GOLDENBERG, Felipe; et.al. Reportagem. Desigualdade e preconceito são recorrentes em diversos ambientes do convívio social. Humanista: jornalismo e dirietos humanos, 2018. Disponível em: $<$ https:/www.ufrgs.br/humanista/2018/01/15/transexuais-encontramdificuldades-para-o-acesso-a-educacao-e-trabalho/> Acesso em 7 nov. 2018 GOMEZ, Tchelo; ZYESS, Murillo; BOOMBEAT, Lucas; HARLLEY; GUIGO; APUKE. Quebrada Queer. São Paulo, Rap Box/ Casa 1/ Elemess: 2018. Disponível em <https:/www.vagalume.com.br/rap-box/quebradaqueer.html> Acessado em 18 nov. 2018

GOULART. Gustavo. Reportagem. 'Foi um crime político', diz procuradorgeral de Justiça do Rio sobre caso Marielle. O Globo. 
$<$ https://oglobo.globo.com/rio/foi-um-crime-politico-diz-procurador-geralde-justica-do-rio-sobre-caso-marielle-22775473>. Acesso em 12/11/2018. GUIMARÃES, Virgínia Totti. Direito à cidade e direitos na cidade: integrando as perspectivas social, política e jurídica. Revista de Direito da Cidade. Rio de Janeiro, vol. 9, n. 2, p. 626 665, 2017. Disponível em $<$ http://www.e-publicacoes.uerj.br/index.php/rdc/article/view/27143>. Acesso em 05 set. 2018. - Direito à cidade, comuns urbanos $e$ privatização de espaços públicos na Cidade do Rio de Janeiro: os casos da Marina da Gloria e do Campo de Golfe Olímpico. Rio de Janeiro. 2016. 275 p. Tese (Doutorado em Direito) Departamento de Direito da PUC-Rio. HARVEY, David. Cidades Rebeldes: Do Direito à Cidade à Revolução Urbana. $1^{a}$ ed.. São Paulo: Martins Fontes, 2014.

Direito à cidade. Disponível em:
$<$ http://revistas.pucsp.br/index.php/ls/article/view/18497/13692>. Acesso em 23 out. 2018.

HCM, Pedro. Reportagem. OAB recomenda que LGBTs se casem até o fim do ano pra evitar perda de direitos em governo Bolsonaro. Põe na Roda, 2018 b Disponível em <https://poenaroda.com.br/diversidade/oabrecomenda-que-lgbts-se-casem-ate-o-fim-do-ano-pra-evitar-perda-dedireitos-em-governo-bolsonaro/>. Acesso em 12/11/2018. . Bolsonaro se compromete a barrar avanços em seu governo. Põe na Roda, 2018a Disponível em $<$ http://www.justificando.com/2018/10/09/maior-plataforma-de-games-domundo-vende-jogo-em-que-bolsonaro-precisa-matar-negros-mulheres-ehomossexuais/>. Acesso em 12/11/2018.

ISOPORZINHO DAS SAPATÃO. Sociabilidade e cultura sapatão. 2018. Disponível em <https://www.facebook.com/IsoporzinhodasSapatao/> Acesso em 27 out. 2018. 
ISTOÉ. Reportagem. Candidatos do PSL destroem placa com homenagem a Marielle Franco. Revista Istoé, 2018a. <https://istoe.com.br/candidatos-dopsl-destroem-placa-com-homenagem-a-marielle-franco/>. Acesso em 12/11/2018.

JUNQUEIRA, Rogério Diniz. Homofobia: limites de um conceito em meio a disputas. Disponível em: $<$ http://www.cchla.ufrn.br/bagoas/v01n01art07_junqueira.pdf $>$. Acesso em 17 out. 2018.

KER, João. Reportagem. Gabriel Ferreira, híbridx: "como se inserir no mundo quando além de preto, você também é viado?”. Revista Híbrida, 2017. Disponível em <https://revistahibrida.com.br/2017/11/07/gabrielferreira-hibridx-como-se-inserir-no-mundo-quando-alem-de-preto-vocetambem-e-viado/> Acesso em 19 nov. 2018.

KOMENTANI, Pâmela. Reportagem. Transexuais enfrentam barreiras para conseguir aceitação no mercado de trabalho. Globo, 2017. Disponível em $<$ https://g1.globo.com/economia/concursos-e-emprego/noticia/transexuaisenfrentam-barreiras-para-conseguir-aceitacao-no-mercado-detrabalho.ghtml> Acesso em 5 nov. 2018. LEÃO, Marina. Os unicórnios no fim do arco-íris: bissexualidade feminina, identidades e política no Seminário Nacional de Lésbicas e Mulheres Bissexuais. Rio de Janeiro, 2018. 117 p. Dissertação (Mestrado em Medicina Social) Instituto de Medicina Social da UERJ.

LEFEBVRE, Henri. O direito à cidade. $5^{\mathrm{a}}$ ed.. São Paulo: Centauro, 2001. LOPES, Ana Carolina Mattoso. O Direito Social ao Lazer em Perspectiva Crítica: Desigualdades e Democratização do Acesso. Rio de Janeiro. 2017. 197 p. Dissertação (Mestrado em Direito) Departamento de Direito da PUC-Rio.

MARCONDES, Mariana M. Sobre cidade, não-lugar e sexualidade das mulheres. In: KAOTZ, Vanessa; MARQUES, Helena Duarte; CERQUEIRA, Jessica Tavares (Org.). Direito à Cidade: uma visão de gênero. São Paulo: IBDU, 2017. p. 88-93. 
MARCUSE, Peter. $\mathrm{O}$ direito nas cidades e o direito à cidade? In: SUGRANYES, Ana; MATHIVET, Charlotte (Org.).Ciudades para tod@s: Por el derecho a la ciudad, propuestas y experiências. Santiago de Chile: Habitat International Coalition, 2010, p. 89-102. Disponível em: $<$ http://www.hic- al.org/documento.cfm?id_documento=1402>. Acesso em 20 set. 2018.

MC LINN DA QUEBRADA. Mulher. São Paulo: Estúdio YB Music, 2017. Disponível em <https://www.letras.mus.br/mc-linn-da-quebrada/mulher/> Acesso em 10 nov. 2018.

MIÑOSO, Yuderkys Espinosa. Escritos de una lesbiana oscura: reflexiones críticas sobre feminismo y política de identidad en América Latina. $1^{\mathrm{a}}$ ed.. Buenos Aires: En la frontera, 2007.

MODOOD, Tariq. A Basis for and Two Obstacles in the Way of a Multiculturalist Tradition: British Journal of Sociology: Revista do London School of Economics. London, Vol. 59, n.01, 2008.

MONICA, Eder Fernandes; MARTINS, Ana Paula Antunes. Qual o futuro da sexualidade no Direito? $1^{\mathrm{a}}$ ed.. Belo Horizonte: Editora Bonecker Ltda, 2017. 394 p.

MOREIRA, Cintia. Reportagem. A cada 25 horas uma pessoa LGBTI+ (lésbicas, gays, bissexuais, travestis, transexuais e transgêneros, intersexuais) morre no país. ABN, 2017. Disponível em < http://www.aguaboanews.com.br/noticias/exibir.asp?id=12390\&noticia=a cada_25_horas_uma_pessoa_lgbti_lesbicas_gays_bissexuais_travestis_tran sexuais_e_transgeneros_intersexuais_morre_no_pais $>$ Acesso em 7 nov. 2018.

MOREIRA, Fabiano. Reportagem. Eventos como isoporzinho das sapatão e velcro atraem novos grupos de meninas que curtem meninas. Globo, 2015. Disponível em $\quad<$ https://agenciapatriciagalvao.org.br/mulheres-deolho/eventos-como-isoporzinho-das-sapatao-e-velcro-atraem-novos-gruposde-meninas-que-curtem-meninas/> Acesso em 19 nov. 2018. 
MOTT, Luiz; MICHELS, Eduardo; Paulinho. Relatório 2017: Mortes violentas de LGBTI no Brasil. Bahia: Grupo Gay da Bahia, 2017. Disponível

em

$<$ https:/homofobiamata.files.wordpress.com/2017/12/relatorio-2081.pdf $>$ Acesso em 5 outubro, 2018.

NOSSO AMOR EXISTE. Reportagem. O Levante ao Ferro’s Bar: A história não contada do 'Stonewall' brasileiro. Nosso Amor existe. Disponível em <http://www.nossoamorexiste.com/2016/10/o-levante-aoferros-bar-a-historia-nao-contada-do-stonewall-brasileiro/>. Acesso em $13 / 11 / 2018$

Notícias ao Minuto. Reportagem. Após matar homossexual, suspeito teria gritado 'viva Bolsonaro'. Notícias ao Minuto. Disponível em $<$ https://www.noticiasaominuto.com.br/justica/662434/apos-matarhomossexual-suspeito-teria-gritado-viva-bolsonaro>. Acesso em $12 / 11 / 2018$

OLIVA, Thiago. Minorias Sexuais enquanto 'Grupo Social' e o Reconhecimento do Status de Refugiado no Brasil. São Paulo: ACNUR, 2012. Disponível em $<$ https://www.acnur.org/fileadmin/Documentos/portugues/eventos/Minorias _Sexuais_enquanto_Grupo_Social.pdf?view=1> Acesso em 19 nov. 2018 OLIVEIRA. Carolina. Reportagem. Gigante dos games vende jogo em que Bolsonaro precisa matar negros, mulheres e homossexuais. Justificando. Disponível em $\quad<$ http://www.justificando.com/2018/10/09/maiorplataforma-de-games-do-mundo-vende-jogo-em-que-bolsonaro-precisamatar-negros-mulheres-e-homossexuais/>. Acesso em 12/11/2018.

OSORIO, Leticia. Direito à cidade como um direito humano coletivo. In: ALFONSIN, Betânia; FERNANDES, Edésio (Org.). Direito urbanístico: estudos brasileiros e internacionais. Belo Horizonte: Del Rey, 2006, p. 193214. 
. The world charter on the right to the city. In: UNESCO

(Org.). International Public Debate: Urban Policies and the Right to the City. Paris: UNESCO, 2005. p. 106-110. Disponível em: $<$ http://unesdoc.unesco.org/images/0014/001461/146179m.pdf $>$ Acesso em 18 nov. 2018.

PARKER, Richard. Cultura, economia política e construção social da sexualidade. In: LOURO, Guacira Lopes (Org.). O corpo educado: pedagogias da sexualidade. Belo Horizonte: Autêntica, 1999, p.125-150.

PATI, Camila. Reportagem. Esta é a questão do Enem que fez Bolsonaro decidir fiscalizar a prova. Exame. Disponível em $<$ https://exame.abril.com.br/brasil/esta-e-a-questao-do-enem-que-fezbolsonaro-decidir-fiscalizar-a-prova/>. Acesso em 12/11/2018.

PIOVESAN, Flavia. Direitos sociais, econômicos e culturais e direitos civis e políticos. Revista Internacional de Direitos Humanos. São Paulo, n. 1, p. $2148,2004$.

PIRES, Thula Rafaela de Oliveira. Criminalização do Racismo entre política de reconhecimento e meio de legitimação do controle social dos não reconhecidos. Rio de Janeiro, 2013.

QUERINO, Rangel. Reportagem. Brasil é o país que mais mata LGBT no mundo. 2018. ObservatórioG. Disponível em: $<$ https://observatoriog.bol.uol.com.br/noticias/2018/03/brasil-e-o-pais-quemais-mata-lgbts-no-mundo-confirma-relatorio>. Acesso em: 10 out. 2018. REQUEJO, Ferran. Pluralismo cultural e cidadania democrática. Revista Lua Nova. São Paulo, n. 47, p. 91 119, 1999.

REQUIXA, Renato. $O$ Lazer no Brasil. $1^{\text {a }}$ ed.. São Paulo: Editora Brasiliense, 1977.

RIBEIRO, Paola Ijanci. Reportagem. Adoção por casais homossexuais. Conteudo Juridico, Brasilia-DF. 2017. Disponivel em: $<$ http://www.conteudojuridico.com.br/?artigos\&ver=2.589127\&seo=1>. Acesso em: 19 nov. 2018. 
RICH, Adrienne. Compulsory Heterosexuality and Lesbian Existence. Journal of Women's History: Indiana University Press. Indiana, v. 15, n. 03, p. 11-48, outono 2003.

RICHARDSON, Diane. Constructing sexual citizenship: theorizing sexual rights. Critical social policy, Londres, Thousand Oaks e Nova Delhi, n. 62 p. 105-135, 2000.

ROLNIK, Raquel. A Cidade e a Lei: Legislação, Política Urbana e Territórios na Cidade de São Paulo. São Paulo: Brasiliense, 2000.

RUBIN, Gayle. The traffic in women. In REITER, Reyna (Org.). Towardan antropology of women. $1^{\mathrm{a}}$ ed.. Nova York: Monthly Review Press, 1975. $395 \mathrm{p}$.

SABSAY, Leticia. Fronteras Sexuales: Espacio urbano, cuerpos y ciudadanía. $1^{a}$ ed.. Buenos Aires: Paidós, 2011. 176 p.

SAMPAIO, Paulo. Reportagem. Disque 100, para vítimas LGBT, registrou aumento de $26 \%$ depois do $1^{\text {o }}$ turno. Uol, 2018. Disponível em $<$ https://paulosampaio.blogosfera.uol.com.br/2018/11/08/disque-100-paravitimas-lgbt-registrou-aumento-de-26-depois-do-1oturno/?utm_source=chrome\&utm_medium $=$ webalert\&utm_campaign=paul o-sampaio $>$ Acesso em 20 out. 2018.

SANTILLI, Juliana. Os "novos" direitos socioambientais. Revista Direito e Justiça: Revista do Departamento de Direito da PUC-RS. Porto Alegre, ano VI, n. 9, p. 173 200, nov. 2006.

SANTOS, A. M.; MOTTA, M. S. O "bota-abaixo" revisitado: o executivo municipal e as reformas urbanas no Rio de Janeiro (1903-2003). Revista Rio de Janeiro. Rio de Janeiro, n. 10, p. 5 40, mai./ago. 2003.

SAULE JUNIOR, Nelson. O Direito à Cidade como paradigma da governança urbana democrática. Disponível em: $<$ http://www.polis.org.br/uploads/750/750.pdf>. Acesso em 18 nov. 2018. SCHETTINI, Andrea Bandeira de Mello. A Era do Biopoder e o discurso dos direitos humanos: um olhar genealógico a partir da obra de Michel 
Foucault. Rio de Janeiro, 2013. 125 p. Dissertação (Mestrado em Direito) Departamento de Direito da PUC-Rio.

SCOTT, Joan. A invisibilidade da experiência. Projeto história: Revista do Programa de Estudos Pós-graduados de História. São Paulo, n. 16, p. 297325, fev. 1998

SCOTT, Joan. El género, una categoría para el análisis histórico. In: NAVARRO, Marysa; STIMPSON, Catharine R. (Org.). ¿Qué son los estudios de mujeres? Buenos Aires: Fondo de Cultura Económica, 1998. p. 22-39.

SILVA, Tomaz Tadeu. A produção social da identidade e da diferença. In: SILVA, Tomaz Tadeu (Org.). Identidade e diferença: a perspectiva dos estudos culturais. Rio de Janeiro: Vozes, 2014. p. 73-102.

SILVEIRA, Daniel. Reportagem. Grupo promove 'beijaço' contra a homofobia na Zona Sul do Rio. G1, 2015. Disponível em $<$ http://g1.globo.com/rio-de-janeiro/noticia/2015/03/grupo-promovebeijaco-contra-homofobia-na-zona-sul-do-rio.html> Acesso em 8 out. 2018. SOLOMON, Andrew. Longe da árvore: Pais, filhos e a busca da identidade. $1^{\mathrm{a}}$ ed.. Rio de Janeiro: Companhia das Letras, 2013. 1056 p. SOUZA FILHO, Carlos Frederico Marés de. O direito de ser povo. In: SARMENTO, Daniel; IKAWA, Daniela; PIOVESAN, Flávia (Org.). Igualdade, diferença e direitos humanos. Rio de Janeiro: Lumen Juris, 2010.

STF, ADIn 4.275. Rel. Ministro Marco Aurélio , 8 de março de 2018. STF, ADIn n. 4277 e ADPF 132, Rel. Ministro Ayres Britto, Brasília, 5 de maio de 2011

STF, RE 670.422 RG/RS. Rel. Ministro Dias Tóffoli. Brasília, 15 de agosto de 2018.

STJ, REsp. 889.852-RS, Rel. Ministro Luis Felipe Salomão, j., Brasília, 10 de agosto de 2010.

SUNDFELD, Carlos Ari. O Estatuto da Cidade e suas diretrizes gerais. In: DALLARI, Adilson Abreu; FERRAZ, Sergio (Org.). Estatuto da Cidade: 
Comentários à Lei federal 10.257/2001. São Paulo: Malheiros, 2008. p. 4560.

TODXS. Setembro Amarelo: a importância de falar sobre o suicídio sendo LGBTI+. $\quad$ Medium, $2018 . \quad$ Disponível em $<$ https://medium.com/todxs/setembro-amarelo-prevencao-suicidio-lgbti24f895afffc7> Acesso em 8 nov. 2018.

TORRES, Ricardo Lobo. O Mínimo Existencial como Conteúdo Essencial dos Direitos Fundamentais. In: SOUZA NETO, Claudio Pereira de; SARMENTO, Daniel (Org). Direitos Sociais: Fundamentos, Judicialização e Direitos Sociais em Espécie. Rio de Janeiro: Lumen Juris, 2008.

TRANS MURDER MONITORING (TMM) RESEARCH PROJECT. Reportagem. 2018. Trans Day of Remembrance (TDoR) 2018 Press Release: 369 reported murders of trans and gender-diverse people in the last year. 2018. Transrespect. Disponível em: $<$ https://transrespect.org/en/tmmupdate-trans-day-of-remembrance-2018/>. Acesso em: 19 nov. 2018.

VELLEDA, Luciano. Reportagem. Ativistas temem escalada de violações aos direitos humanos com Bolsonaro. Rede Brasil Atual. Disponível em $<$ https://www.redebrasilatual.com.br/cidadania/2018/11/ativistas-dedireitos-humanos-denunciam-violacoes-e-o-medo-do-governo-bolsonaro>. Acesso em 12/11/2018.

VERGUEIRO, Viviane Simakawa. Por inflexões decoloniais de corpos e identidades de gênero inconformes: uma análise autoetnográfica da cisgeneridade como normatividade. Salvador, 2015. 224 p. Dissertação (Mestrado em Cultura e Sociedade) Instituto de Humanidades Artes e Ciências da UFBA.

A VOZ DA FAVELA. Reportagem. ANF. Rio de Janeiro, p. 4, out. 2018. WEEKS, Jeffrey. O Corpo e Sexualidade. In. LOURO, Guacira Lopes (org.). $O$ Corpo Educado: pedagogias da sexualidade. $2^{\mathrm{a}}$ ed.. Belo Horizonte: Autêntica, 2000.

WITTIG, Monique. El pensamiento heterosexual y otros ensayos. $1^{\mathrm{a}}$ ed.. Madrid: Egales, 2006. 127 p. 
WOLKMER, Antonio Carlos. Pluralismo e crítica do constitucionalismo na América Latina. In: IX Simpósio Nacional de Direito Constitucional, 2011, Curitiba. Anais, Curitiba, ABDConst., 2010. 143-155 p. . Pluralismo jurídico: Fundamentos de uma nova cultura do direito. São Paulo: Alfa-Omega, 2001. YOSHINO, K. The epistemic contract of bisexual erasure. In Stanford Law Review. Palo Alto: Stanford Law Review, 2000. Disponível em $<$ http://kenjiyoshino.net/articles/ epistemiccontract.pdf $>$. Acesso em 18 nov. 2018.

ZIVI, Karen. Rights and the politics of performativity. In: CARVER, Terrell; CHAMBERS, Samuel A.. Judith Butler's Precarious Politics: critical encounters. Nova York: Routledge, 2008. 